\title{
Molecular Mechanisms to Target Cellular Senescence in Hepatocellular Carcinoma
}

\author{
Constanze Mittermeier ${ }^{1}$, Andreas Konopa ${ }^{2}$ and Susanne Muehlich ${ }^{2, *}$ \\ 1 Cancer Science Institute of Singapore, National University of Singapore, Singapore 117599, Singapore; \\ constanze.mittermeier@nus.edu.sg \\ 2 Department of Chemistry and Pharmacy, Molecular and Clinical Pharmacy, Friedrich-Alexander-Universität \\ Erlangen-Nürnberg, 91058 Erlangen, Germany; andreas.konopa@fau.de \\ * Correspondence: susanne.muehlich@fau.de; Tel.: +49-(0)9131-8565665
}

Received: 3 October 2020; Accepted: 20 November 2020; Published: 25 November 2020

check for updates

\begin{abstract}
Hepatocellular carcinoma (HCC) has emerged as a major cause of cancer-related death and is the most common type of liver cancer. Due to the current paucity of drugs for HCC therapy there is a pressing need to develop new therapeutic concepts. In recent years, the role of Serum Response Factor (SRF) and its coactivators, Myocardin-Related Transcription Factors A and B (MRTF-A and -B), in HCC formation and progression has received considerable attention. Targeting MRTFs results in HCC growth arrest provoked by oncogene-induced senescence. The induction of senescence acts as a tumor-suppressive mechanism and therefore gains consideration for pharmacological interventions in cancer therapy. In this article, we describe the key features and the functional role of senescence in light of the development of novel drug targets for HCC therapy with a focus on MRTFs.
\end{abstract}

Keywords: senescence; HCC; SRF; DLC1; MRTF; senolytics

\section{Introduction}

Hepatocellular carcinoma (HCC) is a malignant cancer of liver cells. It is the sixth most common cancer, accounting for around $5 \%$ of all cancers in the world [1]. With 745,000 registered deaths per year, HCC represents the second common cause of cancer deaths worldwide [2,3]. Furthermore, the incidence of HCC has significantly increased since the 1980s, and hit in 2018 an estimated annual incidence of around 841,000 new cases globally $[1,2,4]$. The disease predominantly affects the male population compared to the female population with a ratio of 4:1 [5]. HCC has an average five-year survival of $<15 \%$ and the high rate of tumor recurrence contributes to the poor outcome in the majority of patients with HCC [6-8]. The etiopathogenesis of HCC is linked to hepatitis B (HBV) and hepatitis C (HCV) viral infection, alcohol consumption and aflatoxin B1 contamination, triggering chronic liver injury and cirrhosis. During this transition, hepatocytes lacking telomerase activity exhibit progressive telomere shortening and DNA damage [9]. As a consequence, oncogenes and cyclin dependent kinase (CDK) inhibitors such as $\mathrm{p} 16^{\mathrm{INK} 4 \mathrm{a}}$ and $\mathrm{p} 21^{\mathrm{Cip} 1}$ are activated to induce a senescence barrier in the preneoplastic cirrhosis stage. Cellular senescence in the liver induces growth arrest in cells at risk of malignant transformation and has mostly been associated with inhibition of HCC growth and progression. In hepatic stellate cells that mainly contribute to extracellular matrix (ECM) production and liver fibrosis, induction of cellular senescence is able to limit liver fibrosis which is considered as the precursor of HCC development [10]. Senescent cells remain metabolically active and secrete cytokines termed "senescence-associated secretory phenotype" (SASP) factors. As a result, cellular senescence inhibits HCC development by prompting clearance of hepatic stellate cells and hepatocytes through a concerted action of innate and adaptive immunity $[10,11]$. SASP factors can reinforce the senescence response in an autocrine and paracrine fashion [11]; however, SASP factors can also have pro-proliferative effects on 
neighbouring cells [12]. Inactivation of major senescence-inducing genes (e.g. p53, p16 ${ }^{\mathrm{INK} 4 \mathrm{a}}$, p15 ${ }^{\mathrm{INK} 4 \mathrm{~b}}$ ) enables neoplastic cells to bypass the senescence barrier [13]. Transformed hepatocytes activate hepatic progenitor cell expansion through releases of galectin-3 and alpha-ketoglutarate [14]. The underlying molecular mechanisms for HCC formation, however, are far from being fully understood and therefore, pathways as well as critical factors involved in HCC development and progression remain to be investigated. Given the implications of cellular senescence and SASP effector functions in HCC development, pro-senescence therapies and concomitant alteration of the SASP might provide new pharmacological avenues for an efficient and personalized HCC treatment.

In this review, we summarize the key features and molecular players of cellular senescence in the light of potential interventions and therapy options for HCC.

\section{Cellular Senescence and Its Molecular Players}

Cellular senescence was initially described by Hayflick and Moorhead in 1961 as the fact that normal somatic cells in culture have a limited ability to proliferate and thus, have a finite number of replicative cycles $[15,16]$. This reduced cell proliferation is explained by telomere shortening. As the DNA polymerase is working only in the $5^{\prime}$ to $3^{\prime}$ direction, it is not able to replicate the lagging strand of the DNA and thus, the cell's telomeres become shorter with each cell division $[17,18]$. In contrast to the replicative senescence that relies on shortened telomeres with each cell division, senescence can also occur in cells upon exposure to environmental stress or different DNA damaging agents, such as reactive oxygen species (ROS) or chemical and biological mutagens, inducing oxidative stress or DNA damage. According to its origin, it is termed stress-induced premature senescence (SIPS) [19-21]. Although the senescence markers and players of cells undergoing SIPS as well as replicative senescence differ, both senescent cell types activate the DNA damage repair (DDR) in response to the induced senescence (see Table 1). The phenomenon of cellular senescence is observed both in pathological as well as in physiological processes such as injury, aging or cancer [22,23]. Moreover, it plays a crucial role in fibrosis, embryogenesis, tissue repair and tissue remodeling [24-26].

Table 1. Senescence markers and molecular players in different types of senescence.

\begin{tabular}{|c|c|c|}
\hline Replicative Senescence & $\begin{array}{l}\text { Stress-Induced Premature } \\
\text { Senescence }\end{array}$ & Oncogene-Induced Senescence \\
\hline $\begin{array}{l}\text { - Shortened Telomeres: } \\
\text { telomeres } \\
\text { progressively shorten } \\
\text { with each cell division } \\
\text { due to end- } \\
\text { replication problem } \\
\text { Activation of DDR at } \\
\text { telomere ends }\end{array}$ & $\begin{array}{l}\text { Reactive oxygen species (ROS): } \\
\text { - } \quad \text { Oxidative Stress } \\
\text { DNA Damage } \\
\text { Activation of DDR }\end{array}$ & 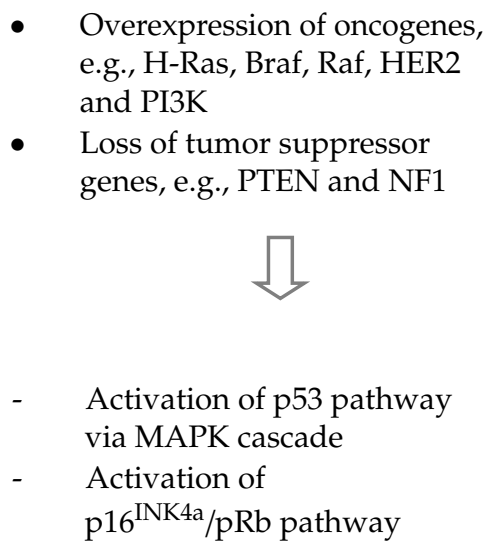 \\
\hline \multicolumn{3}{|c|}{$\begin{array}{ll}\text { - } & \text { enlarged, flat morphology } \\
\text { - } & \text { multi-nucleated } \\
\text { - } & \text { increased } \beta \text {-galactosidase activity at } \mathrm{pH} 6 \\
\text { - } & \text { increased expression of } \gamma-\mathrm{H} 2 \mathrm{Ax} \\
\text { - } & \text { expression of cell cycle inhibitors (e.g., } \mathrm{p} 15^{\mathrm{INK} 4 \mathrm{~b}}, \mathrm{p} 16^{\mathrm{INK} 4 \mathrm{a}} \text { and } \mathrm{p} 21^{\mathrm{Cip} 1} \text { ) }\end{array}$} \\
\hline
\end{tabular}


In 1997, Serrano and colleagues described a novel and different form of senescence: the oncogene-induced senescence (OIS) [27]. This OIS is characterized by a cell cycle arrest elicited by the overexpression of activated oncogenes or by the loss of tumor suppressor genes (see Table 1) [28-31].

Further studies demonstrated that a mitogenic stimulation of cells is required for a senescence response as rodent cells were not able to become senescent in serum-free medium [32,33]. The non-proliferative state of senescent cells acts as a naturally occurring response of cells against stress and can inhibit the proliferation of potentially malignant cells due to a cell cycle arrest. Therefore, the concept of senescence activation emerged as a potential tumor suppressor mechanism [27]. Senescence induction and thus, its tumor suppressing function is driven by many various pathways and a multitude of different stimuli. More than 50 oncogenes that are able to induce OIS are known, thereby underlining the complexity of senescence induction [34]. For example, oncogenic H-Ras and other members of the Ras signaling pathway, such as Braf, Mek and Raf were described to cause an OIS response $[30,35,36]$. Additionally, the overexpression of different oncogenes, such as EGFR, HER2 and PI3K, was shown to drive tumor cells into senescence $[37,38]$. The $\mathrm{p} 16^{\mathrm{INK} 4 \mathrm{a}} / \mathrm{pRb}$ pathway downstream of the small GTPase Ras was revealed as the most relevant pathway and p53 as the second important tumor suppressor pathway for senescence induction and proliferation arrest via the activation of the mitogen-activated protein kinase (MAPK) cascade $[35,36,39,40]$. On the molecular level, the cyclin dependent kinase (CDK) inhibitor and tumor suppressor protein $\mathrm{p} 16^{\mathrm{INK} 4 \mathrm{a}}$ inhibits the CDK4/6 activity and thereby elicits a G1 cell cycle arrest that consequently prevents the phosphorylation of the retinoblastoma $(\mathrm{Rb})$ protein $[27,41,42]$. As a result, $\mathrm{Rb}$ is maintained in its activated, hypophosphorylated state that negatively influences the cell cycle progression from G1 to $S$ phase and thereby causes senescence induction [43-45]. Besides hypophosphorylation of Rb, histone H3 methylation in senescence-associated heterochromatin foci (SAHF) is another characteristic feature of senescent cells [46]. This H3K9me3 mark is essential for senescence and requires constant renewal at distinct target gene promoters due to histone turnover [47]. For information on the important topic of the dynamic nature of senescence in cancer, the reader is referred to an excellent recent review [48].

\section{Role of Serum Response Factor (SRF) and Its Coactivators Myocardin-Related Transcription Factors A and B (MRTF-A and -B) in HCC}

In recent years, the role of Serum Response Factor (SRF) and its coactivators Myocardin-Related Transcription Factors A and B (MRTF-A and -B) in HCC and cellular senescence has attached considerable importance. SRF, a transcription factor that governs fundamental biological processes such as cell migration, cell growth, cytoskeletal organization and differentiation in concert with its coactivators MRTF-A and -B has been shown to trigger HCC formation [49-53]. Furthermore, therapeutic knockdown of MRTFs abolishes tumor growth in HCC cells lacking the tumor suppressor Deleted in Liver Cancer 1 (DLC1) in vitro and in vivo by inducing OIS [54,55]. DLC1 is a Rho GTPase-activating protein (RhoGAP) that is heterozygously deleted in 50\% of liver cancers [56]. Given the frequency of DLC1 loss in liver cancer, unravelling the signaling cascades initiated by DLC1 appears to be an important task to tackle. Work from our laboratory revealed that DLC1 loss leads to nuclear localization and activation of MRTFs [56]. As shown in Figure 1, the loss of DLC1 intensifies RhoA activity [57]. RhoA activation upon DLC1 loss results in actin polymerization, releases MRTFs from binding to monomeric G-actin and enables MRTFs to translocate to the nucleus and to activate gene transcription through SRF binding [58,59]. We found that the actin-binding protein Filamin A (FLNA) is a novel interaction partner of MRTF-A and links changes in actin polymerization to transcriptional activity of SRF [60-62]. The nuclear export of MRTF-A is facilitated by phosphorylation of MRTF-A and its direct binding to G-actin [63-65]. Impairment of MRTF nuclear localization by the newly identified small molecule NS8593 reduces MRTF/SRF-dependent target gene expression and HCC cell proliferation in vitro and in vivo by inducing OIS [54,60,63]. NS8593 is a negative gating modulator of the transient receptor potential cation channel TRPM7 that plays a pivotal role in cell proliferation, survival and development $[66,67]$. Reminiscent of the effects of MRTF depletion, pharmacological 
blockade of TRPM7 by NS8593 provokes growth arrest of HCC xenografts by OIS, characterized by elevated $\mathrm{p} 16^{\mathrm{INK} 4 \mathrm{a}}$ expression and Rb hypophosphorylation $[54,68]$. Another inhibitor of the SRF/MRTF pathway that impairs nuclear localization of MRTF-A is the small molecule CCG-1423 [69]. At present, it is not known whether CCG-1423 affects HCC growth and OIS; however, CCG-1423 has recently been shown to revert the hyperproliferation of Hodgkin Lymphoma (HL) in vitro and in vivo [70]. CCG-1423 inhibits the atypical actin-regulatory protein MICAL-2 and reduces nuclear localization of MRTF-A and MRTF/SRF-dependent gene expression by increasing nuclear G-actin levels [69]. Consistent with this, it has been shown that nuclear activity of MRTF-A is regulated by actin dynamics in the nucleus $[63,71]$.

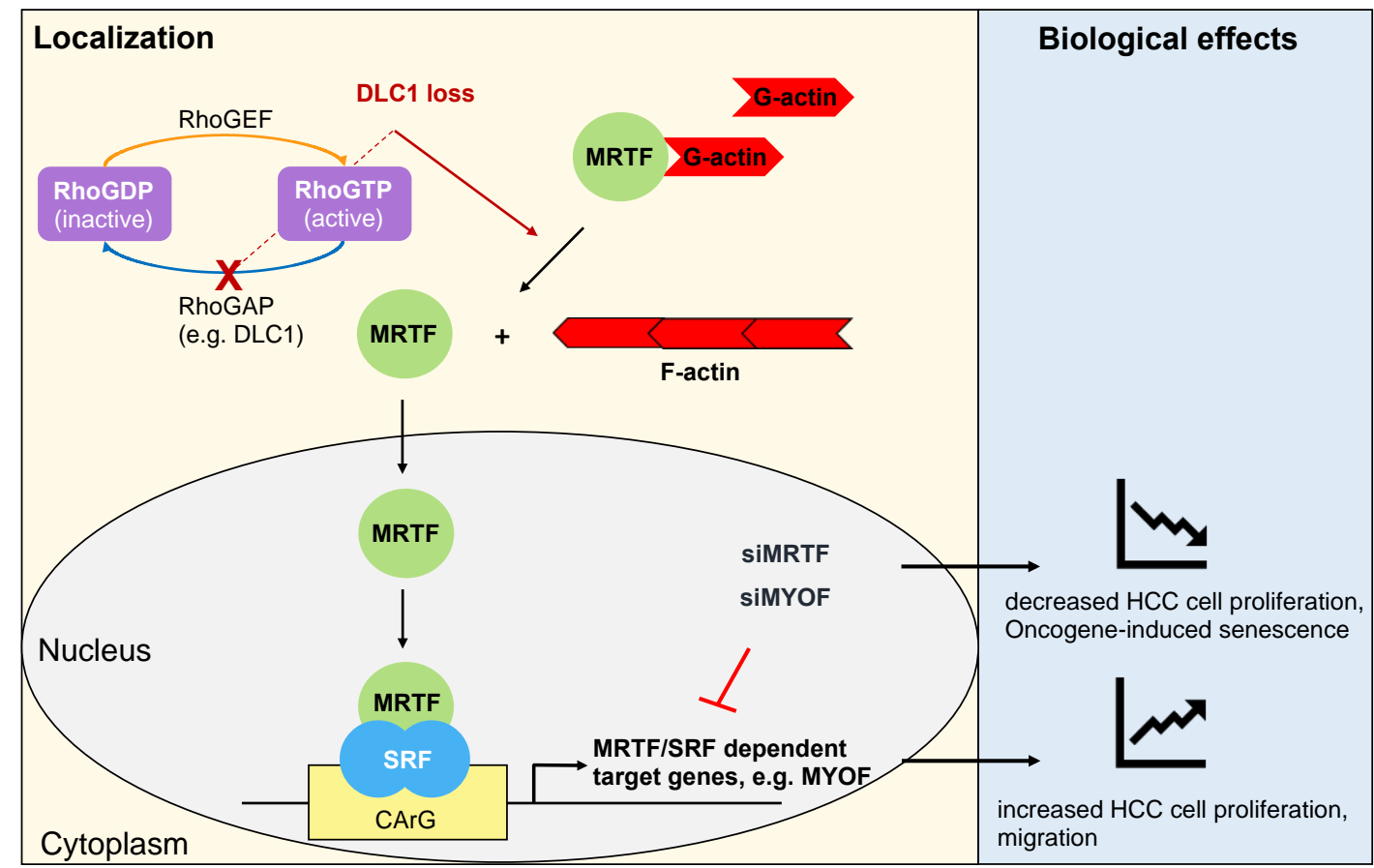

Figure 1. MRTFs and MYOF modulate proliferation and senescence upon DLC1 loss. Loss of the RhoGAP DLC1 results in Rho activation, which leads to actin polymerization, MRTF nuclear localization and expression of MRTF/SRF dependent target genes such as MYOF, resulting in enhanced HCC cell proliferation and migration. Depletion of MRTFs or MYOF inhibits HCC cell proliferation by inducing oncogene-induced senescence.

Several lines of evidence suggest that alterations in the actin cytoskeleton controlled by MRTFs actively participate in the decision of cell proliferation versus senescence. Besides nuclear accumulation of monomeric G-actin, alterations in the actin cytoskeleton linked to cellular senescence include dephosphorylation of the actin-disassembling factor cofilin-1 [72]. Cofilin-1 was also recently described to tightly control the turnover and dynamics of the nuclear F-actin filaments in the daughter cell nuclei after mitotic cell division [73]. Consistent with the fact that phosphorylation of cofilin by LIM kinase (LIMK) 1 prevents the depolymerization of F-actin, inhibition of LIMK 1 activity was observed in senescent cells [72,74]. Furthermore, Rho-associated kinase 1 (ROCK1) expression was significantly reduced in senescent cells [75]. ROCK1 and 2 have extensively been studied as major downstream effectors of RhoA, playing a central role in the coordination of actin dynamics [76,77]. Another activator of MRTF/SRF signaling with an arising role in cancer progression is microtubule-associated serine/threonine kinase-like (MASTL) [78-81]. Mechanistically, MASTL associated with MRTF-A and supported its nuclear retention and transcriptional activity [78]. On a functional level, MASTL promoted contractile actin stress fibers and actomyosin contraction by expression of several MRTF/SRF target genes [78]. Therefore, a RhoA/ROCK/actin-dependent 
mechanism emerges for MRTF/SRF-directed control of transcription in the nucleus and regulation of cellular senescence.

The effects of MRTFs on cellular senescence are mediated by the transmembrane protein Myoferlin (MYOF) via the Ras/MEK/ERK and p16/Rb pathways [82]. Ras activation is facilitated by the activation and phosphorylation of the epidermal growth factor receptor (EGFR) upon MYOF knockdown in HCC cells and xenografts $[82,83]$. MYOF is involved in the stabilization of different receptor tyrosine kinases, such as the insulin-like growth factor (IGF) or the vascular endothelial growth factor (VEGF) receptors, as well as in the modulation of receptor recycling or the degradation rate [84-86]. The finding that MYOF depletion impairs the EGFR degradation and thereby provokes OIS, reflects that the endocytotic activity, and especially the receptor-mediated endocytosis, is significantly decreased in senescent cells $[87,88]$ and explains why senescent cells do not respond properly to external stimuli by growth factors, such as EGF [89]. In cancer cells lacking MYOF, their invasive capacity is reduced due to a reversion of the epithelial-mesenchymal transition (EMT), the mesenchymal-epithelial transition (MET) $[82,90]$. The impaired invasive potential of MYOF depleted senescent cells also results from a significant decrease of matrix metalloproteinase (MMP) production and secretion that promote tumor spread within fibrotic liver tissues [86,91,92]. Correspondingly, HCC is associated with an increased MMP2 expression [93]. Additionally, the NOD-like receptor X1 (NLRX1) inhibits the EMT and the cell's invasiveness by repressing the PI3K-AKT pathway in HCC cells [94]. Because the EMT represents a critical process for HCC progression and NLRX1 overexpression is also associated with the induction of senescence it serves as a tumor suppressor in HCC [94]. Taken together, targeting MRTFs and SRF and its target genes such as MYOF represent promising therapeutic options for HCC by inducing cellular senescence and senescence-associated alterations in the cytoskeleton that cease HCC cell migration and proliferation.

\section{Senescence and Fibrosis}

As senescent cells are known to increase their number with age and have been implicated in several age-related degenerative disorders mainly via the secreted proteins from their SASP, cellular senescence plays an important role in tissue remodeling and fibrotic diseases [95,96]. Fibrosis can occur in many different tissues, such as liver, lung or heart, and is a consequence of dysfunctional tissue maintenance and regeneration due to connective tissue deposition and an accumulation of extracellular matrix proteins leading to permanent scar tissue [97-99]. There is emerging evidence that cellular senescence contributes to the development of idiopathic pulmonary fibrosis (IPF), a progressive lung disorder showing a damage of lung structure and function [100-102]. The molecular mechanisms driving pulmonary fibrosis remain largely uncharacterized and treatment options are currently limited. MRTFs play a key role in lung fibrosis. During the fibrotic process, MRTF-A's and -B's translocation into the nucleus and activation of pro-fibrotic target genes via the RhoA-actin signaling axis takes place [103]. Inhibition of the nuclear accumulation of MRTF-A in lung fibroblasts has been shown to decrease lung fibrosis comparable to a global deletion of MRTF-A in a murine model of fibrosis induced by bleomycin [104]. The involvement of senescence in the pathogenesis of IPF is in line with the finding that IPF is a disease of aging and mainly occurs in older individuals [105-108]. Several different types of cells, such as fibroblasts or epithelial cells, show a senescent phenotype in IPF lungs [109-111] accompanied by enhanced expression of established senescence markers, such as p16 and p21 [100,111,112]. Sustained activation of Wnt/ $\beta$-catenin signaling as well as an aberrant expression of the stem cell marker Nanog were found in senescent IPF fibroblasts [100]. Furthermore, senescent cells secrete elevated amounts of interleukins (IL), including IL-1 $\beta$, IL-6 and IL-8, which can contribute to the differentiation of fibroblasts into myofibroblasts [113]. Underlining the fact that the development and progression of fibrosis are driven by the accumulation and presence of senescent cells, many studies revealed an anti-fibrotic effect due to the elimination of senescent cells that in turn could improve the lung structure and function in aged mice having lung fibrosis and reverse pulmonary fibrosis $[111,114,115]$. Importantly, the clearance of senescent cells by senolytic therapies is able to 
prevent fibrosis and improves the symptoms of fibrosis patients representing a promising treatment option [116,117]. Similarly, senescent cells accumulate in liver fibrosis and cirrhosis, an advanced stage of liver disorder developing from liver fibrosis [118]. HCC is known to be strongly associated with liver fibrosis and cirrhosis, as about $>80 \%$ of HCCs arise in patients with hepatic fibrosis or cirrhosis and approximately one in three patients with liver cirrhosis will develop HCC [7,119]. Since chronic liver injury triggers inflammatory and wound-healing processes and in consequence hepatic fibrosis that may progress to cirrhosis if not treated successfully, it essentially contributes to hepatocarcinogenesis [119-121]. There is mounting evidence that SRF and MRTFs play an important role in liver fibrosis as HCC tumor tissue derived from livers of SRF-VP16 ${ }^{\mathrm{iHep}}$ mice expressing a constitutively active variant of SRF shows a stronger fibrotic microenvironment with increased collagen depositions than the precancerous nodular tissue [122]. From this murine HCC model, a crucial function of miRNAs in controlling liver fibrosis was recently uncovered [122]. A network of miRNAs was revealed to regulate remodeling, signaling and structural components of the fibrotic extracellular matrix (ECM) [122]. ECM remodeling triggers a positive feedback loop that leads to nuclear translocation of MRTFs and the transcriptional coactivator Yes-associated protein (YAP), resulting in increased expression of MRTF/YAP dependent target genes [123]. Several MRTF target genes, such as $\alpha$-smooth muscle actin ( $\alpha$-SMA) and connective tissue growth factor (CTGF), are involved in fibrosis [104,124,125]. Activation of MRTFs [126] and MRTF dependent target gene expression (e.g. $\alpha$-SMA, CTGF) induce the transition of fibroblasts to myofibroblasts that are responsible for the deposition of extracellular matrix components being observed in fibrosis [127-129]. Given that targeting or genetic deletion of MRTF-A disrupted collagen synthesis and deposition and reduced fibrosis in different organs such as lung and kidney $[130,131]$, MRTF inhibitors may open up new opportunities for antifibrotic therapies and avoid drug resistance development caused by ECM deposition. Consistently, the novel MRTF inhibitor CCG-222740 prevented scar tissue formation in a preclinical fibrosis model [132]. The related small molecule CCG-203971 targeting myocardin and MRTF-A resulted in the inhibition of hepatic stellate cells (HSCs) activation, exhibiting a major event in liver fibrosis, by directly inhibiting SRF and MRTF nuclear translocation [133]. Because the authors of the study observed no effect of CCG-203971 on markers of inflammation, a direct effect of the inhibitor on HSCs and liver fibrosis is proposed [133]. These data suggest that targeting the MRTF/SRF signaling pathway represents a promising therapeutic approach to treat liver fibrosis and to prevent the progression to HCC.

\section{Senescence Associated Secretory Phenotype (SASP) and HCC Formation}

Senescence acts as a potent anticancer mechanism and protects neoplastic cells from malignancies on the one hand, while on the other hand it is considered as a driving force of aging and age-related diseases [134-136]. Due to this fact, it is indispensable for the organism to eliminate the senescent cells. The clearance and degradation of senescent cells are accomplished by the immune system [137,138]. The first in vivo evidence for this was obtained from a mosaic mouse model of liver carcinoma, in which RNA interference was used to conditionally regulate the expression of p53 in liver cancer cells $[137,139,140]$. Restoration of endogenous p53 upon establishment of solid tumors led to senescence induction and tumor regression triggered by a senescence-associated secretory phenotype (SASP) mediated immune clearance of senescent liver tumor cells $[137,139,140]$. The SASP that represents a characteristic attribute of senescent cells is of particular importance. The major outcome of the SASP is an activation of an immune reaction rather than a reinforcement of the senescence response. The acquisition of a SASP has the ability to turn senescent cells into pro-inflammatory cells that secrete high levels of adhesion molecules, chemokines, cytokines as well as growth factors that can recruit and activate specific immune cells from the innate and also the adaptive immune system [141-143]. Hepatocytes can generate an SASP mediated inflammatory environment that recruits $\mathrm{CD} 4^{+} \mathrm{T}$ cells and macrophages in response to NRas activation, resulting in subsequent elimination of senescent cells and impairment of NRas induced hepatocarcinogenesis. [144]. The recognition and elimination of senescent cells are carried out by different cell types, mainly by $\mathrm{T}$ cells, monocytes/macrophages 
and natural killer (NK) cells [145-148]. Despite the clearance of senescent cells by the immune system, senescent cells accumulate during aging within different tissues [149]. This incomplete cell elimination and accumulation with age may be explained with a decline in immune function and a permanent weakening of the immune system caused by essential changes in the formation and functionality of immune cells during aging $[139,140]$. As a consequence, the persistence of senescent cells in different tissues and the secretion of SASP factors result in a chronic pro-inflammatory microenvironment and promotes the development of tissue aging and the development of age-related diseases [150-153] (Figure 2). Here, fibrosis, type 2 diabetes, obesity, cardiovascular diseases, sarcopenia, osteoarthritis and neurological disorders are attributed to age-related diseases associated with increased senescence [22,95]. Obesity has recently been recognized as an important factor driving the development of HCC [154]. Changes in gut microbiota caused by obesity promote the release of bacterial metabolites such as deoxycholic acid (DCA), which in turn induce senescence and release of SASP factors in hepatic stellate cells (HSCs) [155]. DCA-induced SASP factors secreted from HSCs promote obesity-associated HCC development due to an enhanced SASP level [156]. In contrast, CCL2-CCR2 proteins classified as SASP factors support the elimination of senescent hepatocytes and thereby suppress HCC formation [11,144]. While SASP factors are able to suppress liver cancer initiation, they can promote tumorigenesis in advanced stages of HCC development, altered secretory activities of senescent cells can promote tumorigenesis due to their immunosuppressive effect and changes in the tissue microenvironment [157]. Several SASP factors are able to enhance the senescence of neighbor cells. The secretion of the interleukins IL-6 and IL-8, or insulin-like growth factor-binding protein 7 (IGFBP7) increases oncogene induced growth arrest caused by Ras and Braf [158-160]. Given the potential implications of the SASP in HCC development, altering the SASP might provide new therapeutic opportunities for the treatment of liver cancer.

\section{Pro-senescence cancer therapy}

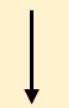

Accumulation of senescent cells
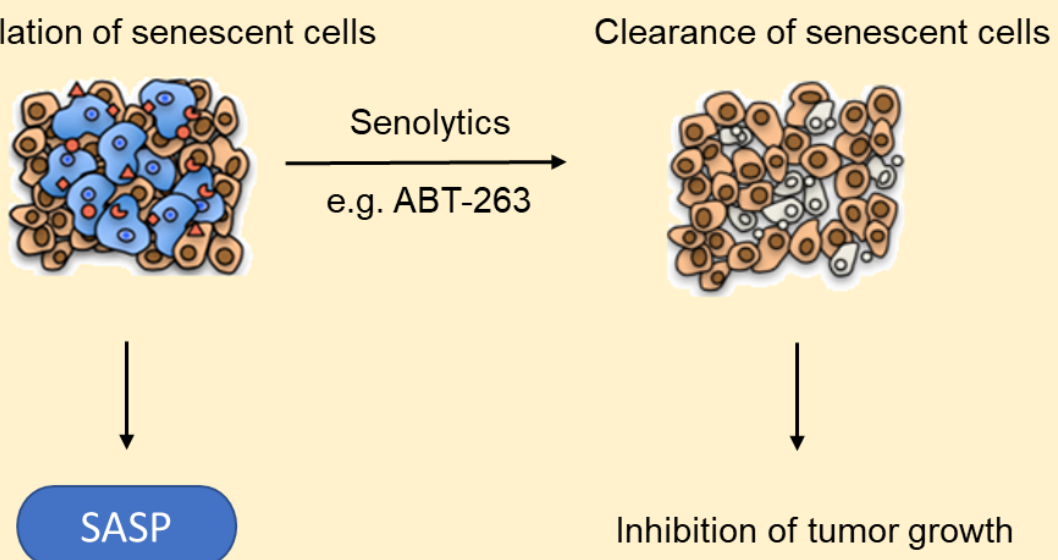

Inhibition of tumor growth

- Development of age-related diseases

- Tumorigenic and anti-tumorigenic properties

Figure 2. Pro-senescence cancer therapies to combat tumor growth. The accumulation of senescent cells in different tissues due to a reduced clearance as a result of, e.g. a compromised immune system leads to an increase in SASP factor secretion. This favors the development of age-related diseases and may counteract antitumor effects. The combination with senolytics may prevent an accumulation of senescent cells and the resulting deleterious effects of the SASP. 


\section{Functional Role of Senescence in Light of the Development of Novel Drug Targets}

For tumor therapy, activating the senescence response emerges as an important and promising strategy to curb tumor growth $[27,30,35,161]$ since it is often disabled in cancer cells [162]. OIS maintains the tumor cell in a premalignant and non-aggressive state thereby restricting the further cell growth, whereas cells not inducing a senescence response progressed to a malignant state $[28,163,164]$. Michaloglou and colleagues demonstrated that human melanocytes with a sustained expression of oncogenic BRAF mutations underwent OIS and remained benign instead of progressing into malignant melanoma $[30,165]$. In this context, the loss of the tumor suppressor phosphatase and tensin homolog (PTEN) in BRAF-mutated cells promotes tumor progression and the development of metastatic melanoma in vivo [29]. Additionally, Kang et al. demonstrated that the induction of senescence in preneoplastic hepatocytes efficiently prevented HCC [144].

Several studies highlighted the importance of novel drugs that induce senescence, such as the CDK4/6 inhibitors Palbociclib, Ribociclib or Abemaciclib showing promising benefits as anticancer compounds [166-169]. The combination of Palbociclib administration with current breast cancer therapies significantly increased the median progression-free survival in clinical trials [168]. Moreover, the inhibition of Src homology region 2-containing protein tyrosine phosphatase 2 (SHP2) prevented invasion and mammary tumor growth in mice due to senescence induction $[170,171]$.

Directed therapeutic intervention depends on a deep understanding of the signaling pathways and molecular players through which OIS is manifest, as described in the section above. Targeted therapies aimed at the selective enhancement of senescence in liver cancer cells could be used for HCC therapy. This approach differs from conventional therapeutic regimens that affect both normal and cancer cells. At the moment, the kinase inhibitors Sorafenib and Lenvatinib are the only by the Food and Drug Administration (FDA) approved drugs for HCC therapy [172-175]; however, the arising of primary or acquired resistance against the drugs is a major issue [175-177]. Due to these limitations, there is a pressing need to identify novel drugs and targets for HCC therapy. To minimize the possible effects of the accumulation of senescent cells and the secretion of SASP factors, which drive human age-related pathologies, senolytics may be beneficial. Senolytics are pharmacologically active compounds with preferential cytotoxic activity for senescent cells [178-180]. Recently it was shown that the loss of the newly discovered HCC suppressor fructose 1,6-bisphosphatase 1 (FBP1) leads to senescence induction in hepatic stellate cells (HSCs) and a related release of SASP, which triggered HCC formation. The use of senolytics such as Dasatinib/Quercetin or Navitoclax (ABT-263) results in the clearance of senescent HSCs and inhibition of HCC progression [181]. Another example is the bromodomain and extra-terminal domain (BET) family protein degrader (BETd) which was identified as a senolytic by high-throughput screening. BETd therapy removes senescent HSCs in adipose mouse liver, thereby inhibiting the progression of liver cancer [182]. Since HCC formation is often associated with SASP release in senescent HSCs, inhibition of SASP release or the reduction of their disease-causing phenotypes as a therapeutic target might be an appropriate approach. This strategy is called senomorphic or senostatic therapy [183]. In comparison to senolytics, senostatics/senomorphics do not eliminate senescent cells, rapamycin for example inhibits the release of SASP via mTor [184]. A dangerous side effect of senomorphics is reduced wound healing due to SASP suppression [185]. Table 2 shows a selection of some SASP inhibitors and senolytics. At the moment, options for eliminating senescent cells for HCC therapy are in a preclinical stage. 
Table 2. Drugs targeting senescence in HCC.

\begin{tabular}{cccc}
\hline $\begin{array}{c}\text { Strategy for Senescent } \\
\text { Cell Elimination }\end{array}$ & Drug & Drug Target & References \\
\hline & Rapamycin & mTor & {$[186,187]$} \\
Sertraline & mTor & {$[188]$} \\
& Torin1 & mTor & {$[189]$} \\
& Pacritinib & JAK2 & {$[190]$} \\
& Ruxolitinib & JAK1/2 & {$[191]$} \\
\hline Senolytics & Dasatinib & Src kinase, BCR/Abl & {$[192,193]$} \\
& Quercetin & Bcl-xL & {$[192,193]$} \\
& A-1331852 & Bcl-xL & {$[194]$} \\
& ABT-263, -737 & Bcl-2, Bcl-xL and & {$[195]$} \\
& XL413 & Bcl-W & {$[188]$} \\
& BETd & CDC7 & {$[182]$} \\
& Ouabain (cardiac & Ba+/K+-ATPase & {$[196]$} \\
\hline \multirow{2}{*}{ Immunotherapy } & glycoside) & NK cell activation & {$[197]$} \\
& Poly(I:C) & uPAR & {$[198]$} \\
\hline
\end{tabular}

Furthermore, Zhu and colleagues reported an upregulation of anti-apoptotic gene sets and negative regulators of apoptosis in senescent compared to nonsenescent cells [116]. Members of this family, such as B-cell lymphoma-extra-large (Bcl-xL), are involved in the regulation of programmed cell death by caspase inhibition. Interestingly, dysregulation of the Bcl-2 family has not only been found in several degenerative diseases but also in different cancers, such as HCCs [199-201]. Introduction of siRNAs against Bcl-xL led to a reduced survival rate in senescent cells whereas proliferating cells were not affected [192]. Consistently, the administration of Navitoclax (ABT-263), a Bcl-2, Bcl-xL and Bcl-W inhibitor, led to apoptosis and eradication of cells in a senescent state [116] (Figure 2). This effect could also be observed in vivo in mice [202]. Furthermore, the clearance of therapy induced senescent cells by senolytics, leads to a decreased incidence of cardiac dysfunction as well as a reduced recurrence of cancer and a lower toxicity of chemotherapy [203]. The related Bcl-2 inhibitor ABT-737 (Table 2) also suppressed growth of hepatoma cells in combination with Sorafenib [202]. Importantly, SRF binds to the Bcl-2 promoter in vivo and activates the transcription of Bcl-2, while the loss of SRF and MRTFs impairs expression of antiapoptotic Bcl-2 family members [204,205]. Targeting MRTF activity as pro-senescence therapy may therefore not only induce senescence but also eradicate senescent cells by Bcl-2 downregulation, thereby mitigating the deleterious effects of the SASP. It will be an interesting task to tackle in the future if a combination therapy with MRTF inhibitors such as NS8593 [66] or CCG-222740 [206] and senolytics might improve outcomes in tumor therapy, particularly in HCC [116].

\section{Conclusions}

The increase in the incidence of HCC and the difficulties to treat HCC owing to the current paucity of drugs highlight the pressing need to develop new pharmacological approaches for systemic therapy $[207,208]$. The induction of senescence represents a novel strategy for the treatment of liver cancer, especially in a one-two punch therapy using a combination of a senescence-inducing drug and a second drug that selectively eliminates senescent cancer cells [209]. The causes underlying this two-step anticancer therapeutic concept rely on the distinct features of cancer-associated senescent cells. Senescence induces not only cell cycle arrest elicited by the overexpression of activated oncogenes or by the loss of tumor suppressor genes and accompanied by alterations in the organization of the actin cytoskeleton, but also a context-dependent senescence-associated secretory phenotype (SASP) that directs their immune-mediated clearance described in this review. While senescence induction acts as a powerful tumor suppressor mechanism, the potential tumor promoting effects of the SASP may drive 
cancer relapse. Therefore, a pro-senescence cancer therapy and subsequent clearance of senescent cells by senolytics, as outlined in Figure 2 and Table 2, has built excitement as a therapeutic intervention and gains even more impetus for liver cancer as the potentially harmful effects associated with aberrant accumulation of senescent cells may be attenuated. Consistent with this, a recent study demonstrated that the anti-depressant Sertraline as well as mTOR inhibitors kill HCC cells that have been rendered senescent by inhibition of cell division cycle 7-related protein kinase (CDC7) which phosphorylates critical substrates regulating the transition from G1 to $S$ phase [188]. Directed therapeutic intervention depends on a profound understanding of the signaling pathways through which cell cycle arrest in G1 phase and cellular senescence is manifest. Pharmacological inhibition of MRTFs induces proliferation arrest due to oncogene-induced senescence (OIS) and inhibits tumor growth in HCC cells in vivo and in vitro [66]. A RhoA/ROCK/actin-dependent mechanism emerges for MRTF/SRF-directed control of cellular senescence, implying a unique therapeutic opportunity to target senescent cells by inhibiting MRTF transcriptional activity. Characterizing the secretome of liver cancer cells treated with MRTF inhibitors is an important task to tackle since the induction of the SASP represents a double-edged sword for tumor control and the detrimental properties of senescent cells make their elimination therapeutically relevant. As shown in Figure 3, the interplay of a pro-senescence therapy, e.g., MRTF or MYOF siRNA application, and a senolytic therapy, e.g. with ABT-263, represents a promising strategy for HCC treatment by positively effecting the bad outcome of an accumulation of harmful SASP due to senescence induction and turning it into a positive outcome for HCC.

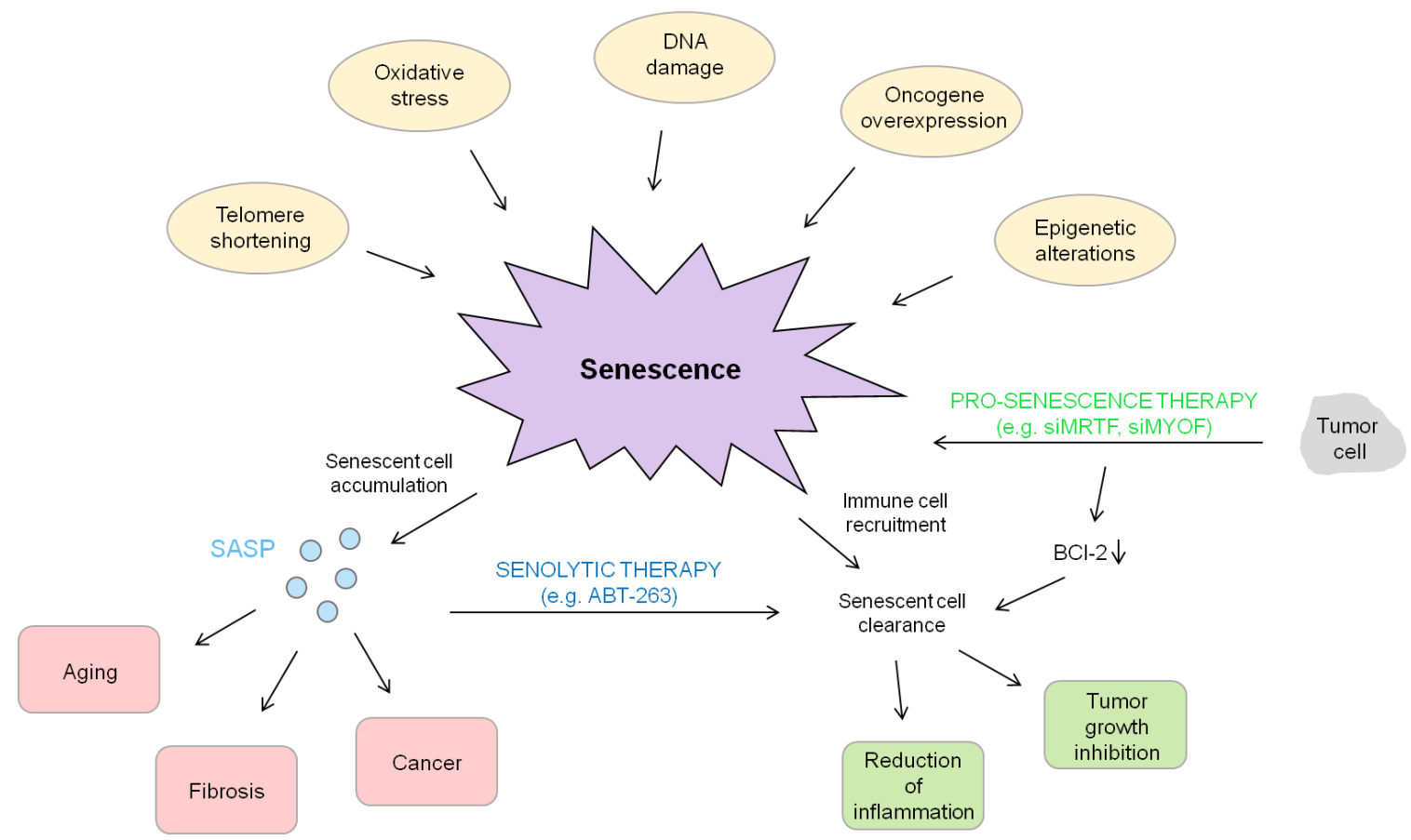

Figure 3. Summary of senescence events. Senescence is activated by a variety of different triggers, such as telomere shortening or oncogene overexpression. On the one hand, an accumulation of senescent cells and the subsequent secretion of SASP can be deleterious by resulting in aging, fibrosis and cancer. On the other hand, the induction of senescence combined with the clearance of senescent cells can be beneficial due to its tumor growth inhibition and suppression.

Given the high heterogeneity of HCC, it is likely that the response towards senescence activators as well as senolytic drugs will vary among patients. Therefore, future interventions regarding senescence therapy in HCC will likely be biomarker-dependent and more personalized. Despite only a limited number of clinical trials on senotherapies so far, it is highly conceivable that this treatment strategy will achieve better outcomes and survival rates for HCC patients. Here, the major 
challenges are the development of more advanced and clinically relevant models, the need for accurate and non-invasive senescent biomarkers that senolytic drugs can specifically target and especially, an increase in the selectivity and specificity of senolytics to reduce potential toxicities. The latter can be optimized by modifying the therapeutic agent that it can be activated by external stimuli. In this context, the drug could be loaded into nanocarriers targeting senescent cells as already described for CD9-targeted delivery of rapamycin using lactose-wrapped calcium carbonate nanoparticles or galacto-oligosaccharide-based nanoparticles utilizing specific $\beta$-galactosidase expression of senescent cells $[210,211]$. The encapsulation of drugs reduces the toxic side effects making them an efficient and selective tool for future HCC senotherapy and might help to facilitate their way to clinical trials although experimental data of applied nanocarrier elimination are still needed.

Overall, senescence induction as well as specific targeting of MRTFs in combination with the identification and application of new and reliable senolytic drugs that clear senescent cells may provide a promising therapeutic modality for personalized HCC therapies in the future.

Author Contributions: Conceptualization, S.M.; Funding Acquisition, S.M.; Writing, S.M., C.M. and A.K. All authors have read and agreed to the published version of the manuscript.

Funding: This work was supported by the Deutsche Forschungsgemeinschaft (MU2737/2-2, GRK1910, MI2596/1-1).

Acknowledgments: We thank all members of the Muehlich laboratory for helpful discussion.

Conflicts of Interest: The authors declare no conflict of interest.

\section{References}

1. Bray, F.; Ferlay, J.; Soerjomataram, I.; Siegel, R.L.; Torre, L.A.; Jemal, A. Global cancer statistics 2018: GLOBOCAN estimates of incidence and mortality worldwide for 36 cancers in 185 countries. CA Cancer J. Clin. 2018, 68, 394-424. [CrossRef]

2. Jemal, A.; Bray, F.; Center, M.M.; Ferlay, J.; Ward, E.; Forman, D. Global cancer statistics. CA Cancer J. Clin. 2011, 61, 69-90. [CrossRef] [PubMed]

3. Ferlay, J.; Soerjomataram, I.; Dikshit, R.; Eser, S.; Mathers, C.; Rebelo, M.; Parkin, D.M.; Forman, D.; Bray, F. Cancer incidence and mortality worldwide: Sources, methods and major patterns in GLOBOCAN 2012. Int. J. Cancer 2015, 136, E359-E386. [CrossRef] [PubMed]

4. Binder-Foucard, F.; Bossard, N.; Delafosse, P.; Belot, A.; Woronoff, A.S.; Remontet, L.; the French Network of Cancer Registries. Cancer incidence and mortality in France over the 1980-2012 period: Solid tumors. Rev. Epidemiol Sante Publique 2014, 62, 95-108. [CrossRef]

5. Farazi, P.A.; DePinho, R.A. Hepatocellular carcinoma pathogenesis: From genes to environment. Nat. Rev. Cancer 2006, 6, 674-687. [CrossRef] [PubMed]

6. El-Serag, H.B.; Rudolph, K.L. Hepatocellular carcinoma: Epidemiology and molecular carcinogenesis. Gastroenterology 2007, 132, 2557-2576. [CrossRef]

7. El-Serag, H.B. Hepatocellular carcinoma. N. Engl. J. Med. 2011, 365, 1118-1127. [CrossRef]

8. Mazzanti, R.; Gramantieri, L.; Bolondi, L. Hepatocellular carcinoma: Epidemiology and clinical aspects. Mol. Asp. Med. 2008, 29, 130-143. [CrossRef]

9. Badvie, S. Hepatocellular carcinoma. Postgrad. Med. J. 2000, 76, 4-11. [CrossRef]

10. Krizhanovsky, V.; Yon, M.; Dickins, R.A.; Hearn, S.; Simon, J.; Miething, C.; Yee, H.; Zender, L.; Lowe, S.W. Senescence of activated stellate cells limits liver fibrosis. Cell 2008, 134, 657-667. [CrossRef]

11. Acosta, J.C.; Banito, A.; Wuestefeld, T.; Georgilis, A.; Janich, P.; Morton, J.P.; Athineos, D.; Kang, T.-W.; Lasitschka, F.; Andrulis, M. A complex secretory program orchestrated by the inflammasome controls paracrine senescence. Nat. Cell Biol. 2013, 15, 978-990. [CrossRef] [PubMed]

12. Pérez-Mancera, P.A.; Young, A.R.; Narita, M. Inside and out: The activities of senescence in cancer. Nat. Rev. Cancer 2014, 14, 547-558. [CrossRef] [PubMed]

13. Ozturk, M.; Arslan-Ergul, A.; Bagislar, S.; Senturk, S.; Yuzugullu, H. Senescence and immortality in hepatocellular carcinoma. Cancer Lett. 2009, 286, 103-113. [CrossRef] [PubMed] 
14. Tummala, K.S.; Brandt, M.; Teijeiro, A.; Graña, O.; Schwabe, R.F.; Perna, C.; Djouder, N. Hepatocellular carcinomas originate predominantly from hepatocytes and benign lesions from hepatic progenitor cells. Cell Rep. 2017, 19, 584-600. [CrossRef]

15. Hayflick, L.; Moorhead, P.S. The serial cultivation of human diploid cell strains. Exp. Cell Res. 1961, 25, 585-621. [CrossRef]

16. Hayflick, L. Advances in Tissue Culture Methods Important to Viral Disease Problems. Postgrad. Med. 1964, 35, 503-511. [CrossRef]

17. d'Adda di Fagagna, F.; Teo, S.-H.; Jackson, S.P. Functional links between telomeres and proteins of the DNA-damage response. Genes Dev. 2004, 18, 1781-1799. [CrossRef]

18. Harley, C.B. Telomere loss: Mitotic clock or genetic time bomb? Mutat. Res. Dnaging 1991, 256, $271-282$. [CrossRef]

19. Brack, C.; Lithgow, G.; Osiewacz, H.; Toussaint, O. EMBO WORKSHOP REPORT: Molecular and cellular gerontology Serpiano, Switzerland, September 18-22, 1999. Embo J. 2000, 19, 1929-1934. [CrossRef]

20. Toussaint, O.; Medrano, E.E.; von Zglinicki, T. Cellular and molecular mechanisms of stress-induced premature senescence (SIPS) of human diploid fibroblasts and melanocytes. Exp. Gerontol. 2000, 35, 927-945. [CrossRef]

21. Toussaint, O.; Royer, V.; Salmon, M.; Remacle, J. Stress-induced premature senescence and tissue ageing. Biochem. Pharm. 2002, 64, 1007-1009. [CrossRef]

22. van Deursen, J.M. The role of senescent cells in ageing. Nature 2014, 509, 439-446. [CrossRef]

23. Calcinotto, A.; Kohli, J.; Zagato, E.; Pellegrini, L.; Demaria, M.; Alimonti, A. Cellular Senescence: Aging, Cancer, and Injury. Physiol. Rev. 2019, 99, 1047-1078. [CrossRef] [PubMed]

24. Jun, J.I.; Lau, L.F. The matricellular protein CCN1 induces fibroblast senescence and restricts fibrosis in cutaneous wound healing. Nat. Cell Biol. 2010, 12, 676-685. [CrossRef] [PubMed]

25. Munoz-Espin, D.; Canamero, M.; Maraver, A.; Gomez-Lopez, G.; Contreras, J.; Murillo-Cuesta, S.; Rodriguez-Baeza, A.; Varela-Nieto, I.; Ruberte, J.; Collado, M.; et al. Programmed cell senescence during mammalian embryonic development. Cell 2013, 155, 1104-1118. [CrossRef] [PubMed]

26. Davaapil, H.; Brockes, J.P.; Yun, M.H. Conserved and novel functions of programmed cellular senescence during vertebrate development. Development 2017, 144, 106-114. [CrossRef]

27. Serrano, M.; Lin, A.W.; McCurrach, M.E.; Beach, D.; Lowe, S.W. Oncogenic ras provokes premature cell senescence associated with accumulation of p53 and p16INK4a. Cell 1997, 88, 593-602. [CrossRef]

28. Braig, M.; Lee, S.; Loddenkemper, C.; Rudolph, C.; Peters, A.H.; Schlegelberger, B.; Stein, H.; Dorken, B.; Jenuwein, T.; Schmitt, C.A. Oncogene-induced senescence as an initial barrier in lymphoma development. Nature 2005, 436, 660-665. [CrossRef]

29. Chen, Z.; Trotman, L.C.; Shaffer, D.; Lin, H.K.; Dotan, Z.A.; Niki, M.; Koutcher, J.A.; Scher, H.I.; Ludwig, T.; Gerald, W.; et al. Crucial role of p53-dependent cellular senescence in suppression of Pten-deficient tumorigenesis. Nature 2005, 436, 725-730. [CrossRef]

30. Michaloglou, C.; Vredeveld, L.C.; Soengas, M.S.; Denoyelle, C.; Kuilman, T.; van der Horst, C.M.; Majoor, D.M.; Shay, J.W.; Mooi, W.J.; Peeper, D.S. BRAFE600-associated senescence-like cell cycle arrest of human naevi. Nature 2005, 436, 720-724. [CrossRef]

31. Courtois-Cox, S.; Jones, S.L.; Cichowski, K. Many roads lead to oncogene-induced senescence. Oncogene 2008, 27, 2801-2809. [CrossRef] [PubMed]

32. Mathon, N.F.; Malcolm, D.S.; Harrisingh, M.C.; Cheng, L.; Lloyd, A.C. Lack of replicative senescence in normal rodent glia. Science 2001, 291, 872-875. [CrossRef] [PubMed]

33. Tang, D.G.; Tokumoto, Y.M.; Apperly, J.A.; Lloyd, A.C.; Raff, M.C. Lack of replicative senescence in cultured rat oligodendrocyte precursor cells. Science 2001, 291, 868-871. [CrossRef] [PubMed]

34. Gorgoulis, V.G.; Halazonetis, T.D. Oncogene-induced senescence: The bright and dark side of the response. Curr. Opin. Cell Biol. 2010, 22, 816-827. [CrossRef] [PubMed]

35. Lin, A.W.; Barradas, M.; Stone, J.C.; van Aelst, L.; Serrano, M.; Lowe, S.W. Premature senescence involving p53 and p16 is activated in response to constitutive MEK/MAPK mitogenic signaling. Genes Dev. 1998, 12, 3008-3019. [CrossRef]

36. Zhu, J.; Woods, D.; McMahon, M.; Bishop, J.M. Senescence of human fibroblasts induced by oncogenic Raf. Genes Dev. 1998, 12, 2997-3007. [CrossRef] [PubMed] 
37. Angelini, P.D.; Zacarias Fluck, M.F.; Pedersen, K.; Parra-Palau, J.L.; Guiu, M.; Bernado Morales, C.; Vicario, R.; Luque-Garcia, A.; Navalpotro, N.P.; Giralt, J.; et al. Constitutive HER2 signaling promotes breast cancer metastasis through cellular senescence. Cancer Res. 2013, 73, 450-458. [CrossRef]

38. Garbers, C.; Kuck, F.; A paricio-Siegmund, S.; Konzak, K.; Kessenbrock, M.; Sommerfeld, A.; Haussinger, D.; Lang, P.A.; Brenner, D.; Mak, T.W.; et al. Cellular senescence or EGFR signaling induces Interleukin 6 (IL-6) receptor expression controlled by mammalian target of rapamycin (mTOR). Cell Cycle 2013, 12, 3421-3432. [CrossRef]

39. Ben-Porath, I.; Weinberg, R.A. The signals and pathways activating cellular senescence. Int. J. Biochem. Cell Biol. 2005, 37, 961-976. [CrossRef]

40. Campisi, J. Senescent cells, tumor suppression, and organismal aging: Good citizens, bad neighbors. Cell 2005, 120, 513-522. [CrossRef]

41. Alcorta, D.A.; Xiong, Y.; Phelps, D.; Hannon, G.; Beach, D.; Barrett, J.C. Involvement of the cyclin-dependent kinase inhibitor p16 (INK4a) in replicative senescence of normal human fibroblasts. Proc. Natl. Acad. Sci. USA 1996, 93, 13742-13747. [CrossRef] [PubMed]

42. Hara, E.; Smith, R.; Parry, D.; Tahara, H.; Stone, S.; Peters, G. Regulation of p16CDKN2 expression and its implications for cell immortalization and senescence. Mol. Cell Biol. 1996, 16, 859-867. [CrossRef] [PubMed]

43. Peeper, D.S.; van der Eb, A.J.; Zantema, A. The G1/S cell-cycle checkpoint in eukaryotic cells. Biochim. Biophys. Acta 1994, 1198, 215-230. [CrossRef]

44. Weinberg, R.A. The retinoblastoma protein and cell cycle control. Cell 1995, 81, 323-330. [CrossRef]

45. Chicas, A.; Wang, X.; Zhang, C.; McCurrach, M.; Zhao, Z.; Mert, O.; Dickins, R.A.; Narita, M.; Zhang, M.; Lowe, S.W. Dissecting the unique role of the retinoblastoma tumor suppressor during cellular senescence. Cancer Cell 2010, 17, 376-387. [CrossRef]

46. Narita, M.; Nũnez, S.; Heard, E.; Narita, M.; Lin, A.W.; Hearn, S.A.; Spector, D.L.; Hannon, G.J.; Lowe, S.W. $\mathrm{Rb}$-mediated heterochromatin formation and silencing of $\mathrm{E} 2 \mathrm{~F}$ target genes during cellular senescence. Cell 2003, 113, 703-716. [CrossRef]

47. Milanovic, M.; Fan, D.N.; Belenki, D.; Däbritz, J.H.M.; Zhao, Z.; Yu, Y.; Dörr, J.R.; Dimitrova, L.; Lenze, D.; Barbosa, I.A.M. Senescence-associated reprogramming promotes cancer stemness. Nature 2018, 553, 96-100. [CrossRef]

48. Lee, S.; Schmitt, C.A. The dynamic nature of senescence in cancer. Nat. Cell Biol. 2019, 21, 94-101. [CrossRef]

49. Ohrnberger, S.; Thavamani, A.; Braeuning, A.; Lipka, D.B.; Kirilov, M.; Geffers, R.; Autenrieth, S.E.; Romer, M.; Zell, A.; Bonin, M.; et al. Dysregulated serum response factor triggers formation of hepatocellular carcinoma. Hepatology 2015, 61, 979-989. [CrossRef]

50. Kim, K.R.; Bae, J.S.; Choi, H.N.; Park, H.S.; Jang, K.Y.; Chung, M.J.; Moon, W.S. The role of serum response factor in hepatocellular carcinoma: An association with matrix metalloproteinase. Oncol. Rep. 2011, 26, 1567-1572.

51. Kwon, C.Y.; Kim, K.R.; Choi, H.N.; Chung, M.J.; Noh, S.J.; Kim, D.G.; Kang, M.J.; Lee, D.G.; Moon, W.S. The role of serum response factor in hepatocellular carcinoma: Implications for disease progression. Int. J. Oncol. 2010, 37, 837-844. [PubMed]

52. Park, M.Y.; Kim, K.R.; Park, H.S.; Park, B.H.; Choi, H.N.; Jang, K.Y.; Chung, M.J.; Kang, M.J.; Lee, D.G.; Moon, W.S. Expression of the serum response factor in hepatocellular carcinoma: Implications for epithelial-mesenchymal transition. Int. J. Oncol. 2007, 31, 1309-1315. [CrossRef] [PubMed]

53. Bae, J.S.; Noh, S.J.; Kim, K.M.; Jang, K.Y.; Chung, M.J.; Kim, D.G.; Moon, W.S. Serum response factor induces epithelial to mesenchymal transition with resistance to sorafenib in hepatocellular carcinoma. Int. J. Oncol. 2014, 44, 129-136. [CrossRef] [PubMed]

54. Hampl, V.; Martin, C.; Aigner, A.; Hoebel, S.; Singer, S.; Frank, N.; Sarikas, A.; Ebert, O.; Prywes, R.; Gudermann, T.; et al. Depletion of the transcriptional coactivators megakaryoblastic leukaemia 1 and 2 abolishes hepatocellular carcinoma xenograft growth by inducing oncogene-induced senescence. Embo Mol. Med. 2013, 5, 1367-1382. [CrossRef] [PubMed]

55. Muehlich, S.; Gudermann, T. Pro-senescence therapy for hepatocellular carcinoma. Aging 2013, 5, 639-640. [CrossRef] [PubMed]

56. Xue, W.; Krasnitz, A.; Lucito, R.; Sordella, R.; Vanaelst, L.; Cordon-Cardo, C.; Singer, S.; Kuehnel, F.; Wigler, M.; Powers, S.; et al. DLC1 is a chromosome 8p tumor suppressor whose loss promotes hepatocellular carcinoma. Genes Dev. 2008, 22, 1439-1444. [CrossRef] [PubMed] 
57. Kim, T.Y.; Vigil, D.; Der, C.J.; Juliano, R.L. Role of DLC-1, a tumor suppressor protein with RhoGAP activity, in regulation of the cytoskeleton and cell motility. Cancer Metastasis Rev. 2009, 28, 77-83. [CrossRef]

58. Miralles, F.; Posern, G.; Zaromytidou, A.I.; Treisman, R. Actin dynamics control SRF activity by regulation of its coactivator MAL. Cell 2003, 113, 329-342. [CrossRef]

59. Posern, G.; Miralles, F.; Guettler, S.; Treisman, R. Mutant actins that stabilise F-actin use distinct mechanisms to activate the SRF coactivator MAL. Embo J. 2004, 23, 3973-3983. [CrossRef]

60. Kircher, P.; Hermanns, C.; Nossek, M.; Drexler, M.K.; Grosse, R.; Fischer, M.; Sarikas, A.; Penkava, J.; Lewis, T.; Prywes, R.; et al. Filamin A interacts with the coactivator MKL1 to promote the activity of the transcription factor SRF and cell migration. Sci. Signal. 2015, 8, ra112. [CrossRef]

61. Muehlich, S.; Hermanns, C.; Meier, M.A.; Kircher, P.; Gudermann, T. Unravelling a new mechanism linking actin polymerization and gene transcription. Nucleus 2016, 7, 121-125. [CrossRef] [PubMed]

62. Olson, E.N.; Nordheim, A. Linking actin dynamics and gene transcription to drive cellular motile functions. Nat. Rev. Mol. Cell Biol. 2010, 11, 353-365. [CrossRef] [PubMed]

63. Vartiainen, M.K.; Guettler, S.; Larijani, B.; Treisman, R. Nuclear actin regulates dynamic subcellular localization and activity of the SRF cofactor MAL. Science 2007, 316, 1749-1752. [CrossRef] [PubMed]

64. Muehlich, S.; Wang, R.; Lee, S.M.; Lewis, T.C.; Dai, C.; Prywes, R. Serum-induced phosphorylation of the serum response factor coactivator MKL1 by the extracellular signal-regulated kinase $1 / 2$ pathway inhibits its nuclear localization. Mol. Cell Biol. 2008, 28, 6302-6313. [CrossRef]

65. Posern, G.; Sotiropoulos, A.; Treisman, R. Mutant actins demonstrate a role for unpolymerized actin in control of transcription by serum response factor. Mol. Biol. Cell 2002, 13, 4167-4178. [CrossRef]

66. Voringer, S.; Schreyer, L.; Nadolni, W.; Meier, M.A.; Woerther, K.; Mittermeier, C.; Ferioli, S.; Singer, S.; Holzer, K.; Zierler, S.; et al. Inhibition of TRPM7 blocks MRTF/SRF-dependent transcriptional and tumorigenic activity. Oncogene 2020, 39, 2328-2344. [CrossRef]

67. Chubanov, V.; Mederos y Schnitzler, M.; Meissner, M.; Schafer, S.; Abstiens, K.; Hofmann, T.; Gudermann, T. Natural and synthetic modulators of SK $(\mathrm{K}(\mathrm{ca}) 2)$ potassium channels inhibit magnesium-dependent activity of the kinase-coupled cation channel TRPM7. Br. J. Pharm. 2012, 166, 1357-1376. [CrossRef]

68. Muehlich, S.; Hampl, V.; Khalid, S.; Singer, S.; Frank, N.; Breuhahn, K.; Gudermann, T.; Prywes, R. The transcriptional coactivators megakaryoblastic leukemia $1 / 2$ mediate the effects of loss of the tumor suppressor deleted in liver cancer 1. Oncogene 2012, 31, 3913-3923. [CrossRef]

69. Lundquist, M.R.; Storaska, A.J.; Liu, T.C.; Larsen, S.D.; Evans, T.; Neubig, R.R.; Jaffrey, S.R. Redox modification of nuclear actin by MICAL-2 regulates SRF signaling. Cell 2014, 156, 563-576. [CrossRef]

70. Record, J.; Sendel, A.; Kritikou, J.S.; Kuznetsov, N.V.; Brauner, H.; He, M.; Nagy, N.; Oliveira, M.M.S.; Griseti, E.; Haase, C.B.; et al. An intronic deletion in megakaryoblastic leukemia 1 is associated with hyperproliferation of B cells in triplets with Hodgkin lymphoma. Haematologica 2020, 105, 1339-1350. [CrossRef]

71. Baarlink, C.; Wang, H.; Grosse, R. Nuclear actin network assembly by formins regulates the SRF coactivator MAL. Science 2013, 340, 864-867. [CrossRef] [PubMed]

72. Kwak, I.H.; Kim, H.S.; Choi, O.R.; Ryu, M.S.; Lim, I.K. Nuclear accumulation of globular actin as a cellular senescence marker. Cancer Res. 2004, 64, 572-580. [CrossRef] [PubMed]

73. Baarlink, C.; Plessner, M.; Sherrard, A.; Morita, K.; Misu, S.; Virant, D.; Kleinschnitz, E.M.; Harniman, R.; Alibhai, D.; Baumeister, S.; et al. A transient pool of nuclear F-actin at mitotic exit controls chromatin organization. Nat. Cell Biol. 2017, 19, 1389-1399. [CrossRef] [PubMed]

74. Yang, N.; Higuchi, O.; Ohashi, K.; Nagata, K.; Wada, A.; Kangawa, K.; Nishida, E.; Mizuno, K. Cofilin phosphorylation by LIM-kinase 1 and its role in Rac-mediated actin reorganization. Nature 1998, 393, 809-812. [CrossRef] [PubMed]

75. Moujaber, O.; Fishbein, F.; Omran, N.; Liang, Y.; Colmegna, I.; Presley, J.F.; Stochaj, U. Cellular senescence is associated with reorganization of the microtubule cytoskeleton. Cell. Mol. Life Sci. 2019, 76, 1169-1183. [CrossRef]

76. Takesono, A.; Heasman, S.J.; Wojciak-Stothard, B.; Garg, R.; Ridley, A.J. Microtubules regulate migratory polarity through Rho/ROCK signaling in T cells. PLoS ONE 2010, 5, e8774. [CrossRef]

77. Loirand, G. Rho Kinases in Health and Disease: From Basic Science to Translational Research. Pharm. Rev. 2015, 67, 1074-1095. [CrossRef] 
78. Taskinen, M.E.; Narva, E.; Conway, J.R.W.; Hinojosa, L.S.; Lilla, S.; Mai, A.; De Franceschi, N.; Elo, L.L.; Grosse, R.; Zanivan, S.; et al. MASTL promotes cell contractility and motility through kinase-independent signaling. J. Cell Biol. 2020, 219. [CrossRef]

79. Alvarez-Fernandez, M.; Sanz-Flores, M.; Sanz-Castillo, B.; Salazar-Roa, M.; Partida, D.; Zapatero-Solana, E.; Ali, H.R.; Manchado, E.; Lowe, S.; VanArsdale, T.; et al. Therapeutic relevance of the PP2A-B55 inhibitory kinase MASTL/Greatwall in breast cancer. Cell Death Differ. 2018, 25, 828-840. [CrossRef]

80. Rogers, S.; McCloy, R.A.; Parker, B.L.; Gallego-Ortega, D.; Law, A.M.K.; Chin, V.T.; Conway, J.R.W.; Fey, D.; Millar, E.K.A.; O'Toole, S.; et al. MASTL overexpression promotes chromosome instability and metastasis in breast cancer. Oncogene 2018, 37, 4518-4533. [CrossRef]

81. Yoon, Y.N.; Choe, M.H.; Jung, K.Y.; Hwang, S.G.; Oh, J.S.; Kim, J.S. MASTL inhibition promotes mitotic catastrophe through PP2A activation to inhibit cancer growth and radioresistance in breast cancer cells. BMC Cancer 2018, 18, 716. [CrossRef] [PubMed]

82. Hermanns, C.; Hampl, V.; Holzer, K.; Aigner, A.; Penkava, J.; Frank, N.; Martin, D.E.; Maier, K.C.; Waldburger, N.; Roessler, S.; et al. The novel MKL target gene myoferlin modulates expansion and senescence of hepatocellular carcinoma. Oncogene 2017, 36, 3464-3476. [CrossRef]

83. Turtoi, A.; Blomme, A.; Bellahcene, A.; Gilles, C.; Hennequiere, V.; Peixoto, P.; Bianchi, E.; Noel, A.; De Pauw, E.; Lifrange, E.; et al. Myoferlin is a key regulator of EGFR activity in breast cancer. Cancer Res. 2013, 73, 5438-5448. [CrossRef]

84. Bernatchez, P.N.; Acevedo, L.; Fernandez-Hernando, C.; Murata, T.; Chalouni, C.; Kim, J.; Erdjument-Bromage, H.; Shah, V.; Gratton, J.P.; McNally, E.M.; et al. Myoferlin regulates vascular endothelial growth factor receptor-2 stability and function. J. Biol. Chem. 2007, 282, 30745-30753. [CrossRef] [PubMed]

85. Demonbreun, A.R.; Posey, A.D.; Heretis, K.; Swaggart, K.A.; Earley, J.U.; Pytel, P.; McNally, E.M. Myoferlin is required for insulin-like growth factor response and muscle growth. FASEB J. 2010, 24, 1284-1295. [CrossRef] [PubMed]

86. Eisenberg, M.C.; Kim, Y.; Li, R.; Ackerman, W.E.; Kniss, D.A.; Friedman, A. Mechanistic modeling of the effects of myoferlin on tumor cell invasion. Proc. Natl. Acad. Sci. USA 2011, 108, 20078-20083. [CrossRef] [PubMed]

87. Park, J.S.; Park, W.Y.; Cho, K.A.; Kim, D.I.; Jhun, B.H.; Kim, S.R.; Park, S.C. Down-regulation of amphiphysin-1 is responsible for reduced receptor-mediated endocytosis in the senescent cells. FASEB J. 2001, 15, 1625-1627. [CrossRef]

88. Park, S.C. Functional recovery of senescent cells through restoration of receptor-mediated endocytosis. Mech. Ageing Dev. 2002, 123, 917-926. [CrossRef]

89. Park, W.Y.; Park, J.S.; Cho, K.A.; Kim, D.I.; Ko, Y.G.; Seo, J.S.; Park, S.C. Up-regulation of caveolin attenuates epidermal growth factor signaling in senescent cells. J. Biol. Chem. 2000, 275, 20847-20852. [CrossRef]

90. Li, R.; Ackerman, W.E., IV; Mihai, C.; Volakis, L.I.; Ghadiali, S.; Kniss, D.A. Myoferlin depletion in breast cancer cells promotes mesenchymal to epithelial shape change and stalls invasion. PLoS ONE 2012, 7, e39766. [CrossRef]

91. Duffy, M.J.; Maguire, T.M.; Hill, A.; McDermott, E.; O'Higgins, N. Metalloproteinases: Role in breast carcinogenesis, invasion and metastasis. Breast Cancer Res. 2000, 2, 252-257. [CrossRef] [PubMed]

92. Hernandez-Gea, V.; Toffanin, S.; Friedman, S.L.; Llovet, J.M. Role of the microenvironment in the pathogenesis and treatment of hepatocellular carcinoma. Gastroenterology 2013, 144, 512-527. [CrossRef] [PubMed]

93. Giannelli, G.; Bergamini, C.; Marinosci, F.; Fransvea, E.; Quaranta, M.; Lupo, L.; Schiraldi, O.; Antonaci, S. Clinical role of MMP-2/TIMP-2 imbalance in hepatocellular carcinoma. Int. J. Cancer 2002, 97, 425-431. [CrossRef] [PubMed]

94. Hu, B.; Ding, G.Y.; Fu, P.Y.; Zhu, X.D.; Ji, Y.; Shi, G.M.; Shen, Y.H.; Cai, J.B.; Yang, Z.; Zhou, J.; et al. NOD-like receptor $\mathrm{X} 1$ functions as a tumor suppressor by inhibiting epithelial-mesenchymal transition and inducing aging in hepatocellular carcinoma cells. J. Hematol. Oncol. 2018, 11, 28. [CrossRef] [PubMed]

95. Munoz-Espin, D.; Serrano, M. Cellular senescence: From physiology to pathology. Nat. Rev. Mol. Cell Biol. 2014, 15, 482-496. [CrossRef] [PubMed]

96. Kirkland, J.L.; Tchkonia, T. Clinical strategies and animal models for developing senolytic agents. Exp. Gerontol 2015, 68, 19-25. [CrossRef] [PubMed]

97. Wynn, T.A. Common and unique mechanisms regulate fibrosis in various fibroproliferative diseases. J. Clin. Investig. 2007, 117, 524-529. [CrossRef] [PubMed] 
98. Wynn, T.A. Cellular and molecular mechanisms of fibrosis. J. Pathol. 2008, 214, 199-210. [CrossRef]

99. Wynn, T.A. Fibrotic disease and the $\mathrm{T}(\mathrm{H}) 1 / \mathrm{T}(\mathrm{H}) 2$ paradigm. Nat. Rev. Immunol. 2004, 4, 583-594. [CrossRef]

100. Chen, X.; Xu, H.; Hou, J.; Wang, H.; Zheng, Y.; Li, H.; Cai, H.; Han, X.; Dai, J. Epithelial cell senescence induces pulmonary fibrosis through Nanog-mediated fibroblast activation. Aging 2019, 12, 242-259. [CrossRef]

101. Liu, R.M.; Liu, G. Cell senescence and fibrotic lung diseases. Exp. Gerontol. 2020, 132, 110836. [CrossRef] [PubMed]

102. Demedts, M.; Costabel, U. ATS/ERS international multidisciplinary consensus classification of the idiopathic interstitial pneumonias. Eur. Respir. J. 2002, 19, 794-796. [CrossRef] [PubMed]

103. Zhou, Y.; Huang, X.; Hecker, L.; Kurundkar, D.; Kurundkar, A.; Liu, H.; Jin, T.H.; Desai, L.; Bernard, K.; Thannickal, V.J. Inhibition of mechanosensitive signaling in myofibroblasts ameliorates experimental pulmonary fibrosis. J. Clin. Investig. 2013, 123, 1096-1108. [CrossRef] [PubMed]

104. Sisson, T.H.; Ajayi, I.O.; Subbotina, N.; Dodi, A.E.; Rodansky, E.S.; Chibucos, L.N.; Kim, K.K.; Keshamouni, V.G.; White, E.S.; Zhou, Y.; et al. Inhibition of myocardin-related transcription factor/serum response factor signaling decreases lung fibrosis and promotes mesenchymal cell apoptosis. Am. J. Pathol. 2015, 185, 969-986. [CrossRef] [PubMed]

105. Selman, M.; Pardo, A. Revealing the pathogenic and aging-related mechanisms of the enigmatic idiopathic pulmonary fibrosis. an integral model. Am. J. Respir. Crit. Care Med. 2014, 189, 1161-1172. [CrossRef]

106. Faner, R.; Rojas, M.; Macnee, W.; Agusti, A. Abnormal lung aging in chronic obstructive pulmonary disease and idiopathic pulmonary fibrosis. Am. J. Respir. Crit. Care Med. 2012, 186, 306-313. [CrossRef]

107. Leung, J.; Cho, Y.; Lockey, R.F.; Kolliputi, N. The Role of Aging in Idiopathic Pulmonary Fibrosis. Lung 2015, 193, 605-610. [CrossRef]

108. Thannickal, V.J. Mechanistic links between aging and lung fibrosis. Biogerontology 2013, 14, 609-615. [CrossRef]

109. Yanai, H.; Shteinberg, A.; Porat, Z.; Budovsky, A.; Braiman, A.; Ziesche, R.; Fraifeld, V.E. Cellular senescence-like features of lung fibroblasts derived from idiopathic pulmonary fibrosis patients. Aging 2015, 7, 664-672. [CrossRef]

110. Alvarez, D.; Cardenes, N.; Sellares, J.; Bueno, M.; Corey, C.; Hanumanthu, V.S.; Peng, Y.; D'Cunha, H.; Sembrat, J.; Nouraie, M.; et al. IPF lung fibroblasts have a senescent phenotype. Am. J. Physiol. Lung Cell Mol. Physiol. 2017, 313, L1164-L1173. [CrossRef]

111. Schafer, M.J.; White, T.A.; Iijima, K.; Haak, A.J.; Ligresti, G.; Atkinson, E.J.; Oberg, A.L.; Birch, J.; Salmonowicz, H.; Zhu, Y.; et al. Cellular senescence mediates fibrotic pulmonary disease. Nat. Commun. 2017, 8, 14532. [CrossRef] [PubMed]

112. Hecker, L.; Logsdon, N.J.; Kurundkar, D.; Kurundkar, A.; Bernard, K.; Hock, T.; Meldrum, E.; Sanders, Y.Y.; Thannickal, V.J. Reversal of persistent fibrosis in aging by targeting Nox4-Nrf2 redox imbalance. Sci. Transl. Med. 2014, 6, 231ra47. [CrossRef] [PubMed]

113. Minagawa, S.; Araya, J.; Numata, T.; Nojiri, S.; Hara, H.; Yumino, Y.; Kawaishi, M.; Odaka, M.; Morikawa, T.; Nishimura, S.L.; et al. Accelerated epithelial cell senescence in IPF and the inhibitory role of SIRT6 in TGF-beta-induced senescence of human bronchial epithelial cells. Am. J. Physiol. Lung Cell Mol. Physiol. 2011, 300, L391-L401. [CrossRef] [PubMed]

114. Lehmann, M.; Korfei, M.; Mutze, K.; Klee, S.; Skronska-Wasek, W.; Alsafadi, H.N.; Ota, C.; Costa, R.; Schiller, H.B.; Lindner, M.; et al. Senolytic drugs target alveolar epithelial cell function and attenuate experimental lung fibrosis ex vivo. Eur. Respir. J. 2017, 50. [CrossRef]

115. Hashimoto, M.; Asai, A.; Kawagishi, H.; Mikawa, R.; Iwashita, Y.; Kanayama, K.; Sugimoto, K.; Sato, T.; Maruyama, M.; Sugimoto, M. Elimination of p19(ARF)-expressing cells enhances pulmonary function in mice. JCI Insight 2016, 1, e87732. [CrossRef] [PubMed]

116. Zhu, Y.; Tchkonia, T.; Fuhrmann-Stroissnigg, H.; Dai, H.M.; Ling, Y.Y.; Stout, M.B.; Pirtskhalava, T.; Giorgadze, N.; Johnson, K.O.; Giles, C.B.; et al. Identification of a novel senolytic agent, navitoclax, targeting the Bcl-2 family of anti-apoptotic factors. Aging Cell 2016, 15, 428-435. [CrossRef] [PubMed]

117. Lim, H.; Park, H.; Kim, H.P. Effects of flavonoids on senescence-associated secretory phenotype formation from bleomycin-induced senescence in BJ fibroblasts. Biochem. Pharm. 2015, 96, 337-348. [CrossRef]

118. Wiemann, S.U.; Satyanarayana, A.; Tsahuridu, M.; Tillmann, H.L.; Zender, L.; Klempnauer, J.; Flemming, P.; Franco, S.; Blasco, M.A.; Manns, M.P.; et al. Hepatocyte telomere shortening and senescence are general markers of human liver cirrhosis. FASEB J. 2002, 16, 935-942. [CrossRef] 
119. Fattovich, G.; Stroffolini, T.; Zagni, I.; Donato, F. Hepatocellular carcinoma in cirrhosis: Incidence and risk factors. Gastroenterology 2004, 127, S35-S50. [CrossRef]

120. Bataller, R.; Brenner, D.A. Liver fibrosis. J. Clin. Investig. 2005, 115, 209-218. [CrossRef]

121. Inokuchi, S.; Aoyama, T.; Miura, K.; Osterreicher, C.H.; Kodama, Y.; Miyai, K.; Akira, S.; Brenner, D.A.; Seki, E. Disruption of TAK1 in hepatocytes causes hepatic injury, inflammation, fibrosis, and carcinogenesis. Proc. Natl. Acad. Sci. USA 2010, 107, 844-849. [CrossRef] [PubMed]

122. Winkler, I.; Bitter, C.; Winkler, S.; Weichenhan, D.; Thavamani, A.; Hengstler, J.G.; Borkham-Kamphorst, E.; Kohlbacher, O.; Plass, C.; Geffers, R.; et al. Identification of Ppargamma-modulated miRNA hubs that target the fibrotic tumor microenvironment. Proc. Natl. Acad. Sci. USA 2020, 117, 454-463. [CrossRef] [PubMed]

123. Girard, C.A.; Lecacheur, M.; Ben Jouira, R.; Berestjuk, I.; Diazzi, S.; Prod'homme, V.; Mallavialle, A.; Larbret, F.; Gesson, M.; Schaub, S.; et al. A Feed-Forward Mechanosignaling Loop Confers Resistance to Therapies Targeting the MAPK Pathway in BRAF-Mutant Melanoma. Cancer Res. 2020, 80, 1927-1941. [CrossRef] [PubMed]

124. Haak, A.J.; Tsou, P.S.; Amin, M.A.; Ruth, J.H.; Campbell, P.; Fox, D.A.; Khanna, D.; Larsen, S.D.; Neubig, R.R. Targeting the myofibroblast genetic switch: Inhibitors of myocardin-related transcription factor/serum response factor-regulated gene transcription prevent fibrosis in a murine model of skin injury. J. Pharm. Exp. 2014, 349, 480-486. [CrossRef] [PubMed]

125. Small, E.M.; Thatcher, J.E.; Sutherland, L.B.; Kinoshita, H.; Gerard, R.D.; Richardson, J.A.; Dimaio, J.M.; Sadek, H.; Kuwahara, K.; Olson, E.N. Myocardin-related transcription factor-a controls myofibroblast activation and fibrosis in response to myocardial infarction. Circ. Res. 2010, 107, 294-304. [CrossRef]

126. Li, Z.; Chen, B.; Dong, W.; Kong, M.; Fan, Z.; Yu, L.; Wu, D.; Lu, J.; Xu, Y. MKL1 promotes endothelial-to-mesenchymal transition and liver fibrosis by activating TWIST1 transcription. Cell Death Dis. 2019, 10, 899. [CrossRef]

127. Tsou, P.S.; Haak, A.J.; Khanna, D.; Neubig, R.R. Cellular mechanisms of tissue fibrosis. 8. Current and future drug targets in fibrosis: Focus on Rho GTPase-regulated gene transcription. Am. J. Physiol. Cell Physiol. 2014, 307, C2-C13. [CrossRef]

128. Yang, Y.; Zhe, X.; Phan, S.H.; Ullenbruch, M.; Schuger, L. Involvement of serum response factor isoforms in myofibroblast differentiation during bleomycin-induced lung injury. Am. J. Respir. Cell Mol. Biol. 2003, 29, 583-590. [CrossRef]

129. Sandbo, N.; Kregel, S.; Taurin, S.; Bhorade, S.; Dulin, N.O. Critical role of serum response factor in pulmonary myofibroblast differentiation induced by TGF-beta. Am. J. Respir. Cell Mol. Biol. 2009, 41, 332-338. [CrossRef]

130. Luchsinger, L.L.; Patenaude, C.A.; Smith, B.D.; Layne, M.D. Myocardin-related transcription factor-A complexes activate type I collagen expression in lung fibroblasts. J. Biol Chem. 2011, 286, 44116-44125. [CrossRef]

131. Elberg, G.; Chen, L.; Elberg, D.; Chan, M.D.; Logan, C.J.; Turman, M.A. MKL1 mediates TGF-beta1-induced alpha-smooth muscle actin expression in human renal epithelial cells. Am. J. Physiol. Ren. Physiol. 2008, 294, F1116-F1128. [CrossRef] [PubMed]

132. Yu-Wai-Man, C.; Spencer-Dene, B.; Lee, R.M.H.; Hutchings, K.; Lisabeth, E.M.; Treisman, R.; Bailly, M.; Larsen, S.D.; Neubig, R.R.; Khaw, P.T. Local delivery of novel MRTF/SRF inhibitors prevents scar tissue formation in a preclinical model of fibrosis. Sci. Rep. 2017, 7, 518. [CrossRef] [PubMed]

133. Shi, Z.; Ren, M.; Rockey, D.C. Myocardin and myocardin-related transcription factor-A synergistically mediate actin cytoskeletal-dependent inhibition of liver fibrogenesis. Am. J. Physiol. Gastrointest Liver Physiol. 2020, 318, G504-G517. [CrossRef] [PubMed]

134. Giaimo, S.; d'Adda di Fagagna, F. Is cellular senescence an example of antagonistic pleiotropy? Aging Cell 2012, 11, 378-383. [CrossRef]

135. Sager, R. Senescence as a mode of tumor suppression. Environ. Health Perspect. 1991, 93, 59-62. [CrossRef]

136. Sharpless, N.E.; Bardeesy, N.; Lee, K.-H.; Carrasco, D.; Castrillon, D.H.; Aguirre, A.J.; Wu, E.A.; Horner, J.W.; DePinho, R.A. Loss of p16 Ink4a with retention of p19 Arf predisposes mice to tumorigenesis. Nature 2001, 413, 86-91. [CrossRef]

137. Xue, W.; Zender, L.; Miething, C.; Dickins, R.A.; Hernando, E.; Krizhanovsky, V.; Cordon-Cardo, C.; Lowe, S.W. Senescence and tumour clearance is triggered by p53 restoration in murine liver carcinomas. Nature 2007, 445, 656-660. [CrossRef] 
138. Hoenicke, L.; Zender, L. Immune surveillance of senescent cells-biological significance in cancer- and non-cancer pathologies. Carcinogenesis 2012, 33, 1123-1126. [CrossRef]

139. Chinn, I.K.; Blackburn, C.C.; Manley, N.R.; Sempowski, G.D. Changes in primary lymphoid organs with aging. Semin. Immunol. 2012, 24, 309-320. [CrossRef]

140. Thompson, H.L.; Smithey, M.J.; Surh, C.D.; Nikolich-Zugich, J. Functional and Homeostatic Impact of Age-Related Changes in Lymph Node Stroma. Front. Immunol. 2017, 8, 706. [CrossRef]

141. Coppe, J.P.; Patil, C.K.; Rodier, F.; Sun, Y.; Munoz, D.P.; Goldstein, J.; Nelson, P.S.; Desprez, P.Y.; Campisi, J. Senescence-associated secretory phenotypes reveal cell-nonautonomous functions of oncogenic RAS and the p53 tumor suppressor. PLoS Biol. 2008, 6, 2853-2868. [CrossRef] [PubMed]

142. Freund, A.; Orjalo, A.V.; Desprez, P.Y.; Campisi, J. Inflammatory networks during cellular senescence: Causes and consequences. Trends Mol. Med. 2010, 16, 238-246. [CrossRef] [PubMed]

143. Sagiv, A.; Krizhanovsky, V. Immunosurveillance of senescent cells: The bright side of the senescence program. Biogerontology 2013, 14, 617-628. [CrossRef] [PubMed]

144. Kang, T.-W.; Yevsa, T.; Woller, N.; Hoenicke, L.; Wuestefeld, T.; Dauch, D.; Hohmeyer, A.; Gereke, M.; Rudalska, R.; Potapova, A. Senescence surveillance of pre-malignant hepatocytes limits liver cancer development. Nature 2011, 479, 547-551. [CrossRef]

145. Gregoire, C.; Chasson, L.; Luci, C.; Tomasello, E.; Geissmann, F.; Vivier, E.; Walzer, T. The trafficking of natural killer cells. Immunol. Rev. 2007, 220, 169-182. [CrossRef]

146. Bromley, S.K.; Mempel, T.R.; Luster, A.D. Orchestrating the orchestrators: Chemokines in control of T cell traffic. Nat. Immunol. 2008, 9, 970-980. [CrossRef]

147. Eggert, T.; Wolter, K.; Ji, J.; Ma, C.; Yevsa, T.; Klotz, S.; Medina-Echeverz, J.; Longerich, T.; Forgues, M.; Reisinger, F; et al. Distinct Functions of Senescence-Associated Immune Responses in Liver Tumor Surveillance and Tumor Progression. Cancer Cell 2016, 30, 533-547. [CrossRef]

148. Prata, L.; Ovsyannikova, I.G.; Tchkonia, T.; Kirkland, J.L. Senescent cell clearance by the immune system: Emerging therapeutic opportunities. Semin. Immunol. 2018, 40, 101275. [CrossRef]

149. Sharpless, N.E.; Sherr, C.J. Forging a signature of in vivo senescence. Nat. Rev. Cancer 2015, 15, $397-408$. [CrossRef]

150. Adams, P.D. Healing and hurting: Molecular mechanisms, functions, and pathologies of cellular senescence. Mol. Cell 2009, 36, 2-14. [CrossRef]

151. Burton, D.G. Cellular senescence, ageing and disease. Age 2009, 31, 1-9. [CrossRef] [PubMed]

152. Campisi, J. Aging, cellular senescence, and cancer. Annu. Rev. Physiol. 2013, 75, 685-705. [CrossRef] [PubMed]

153. Paez-Ribes, M.; Gonzalez-Gualda, E.; Doherty, G.J.; Munoz-Espin, D. Targeting senescent cells in translational medicine. Embo Mol. Med. 2019, 11, e10234. [CrossRef] [PubMed]

154. Caldwell, S.H.; Crespo, D.M.; Kang, H.S.; Al-Osaimi, A.M. Obesity and hepatocellular carcinoma. Gastroenterology 2004, 127, S97-S103. [CrossRef] [PubMed]

155. Loo, T.M.; Kamachi, F.; Watanabe, Y.; Yoshimoto, S.; Kanda, H.; Arai, Y.; Nakajima-Takagi, Y.; Iwama, A.; Koga, T.; Sugimoto, Y. Gut microbiota promotes obesity-associated liver cancer through PGE2-mediated suppression of antitumor immunity. Cancer Discov. 2017, 7, 522-538. [CrossRef] [PubMed]

156. Yoshimoto, S.; Loo, T.M.; Atarashi, K.; Kanda, H.; Sato, S.; Oyadomari, S.; Iwakura, Y.; Oshima, K.; Morita, H.; Hattori, M. Obesity-induced gut microbial metabolite promotes liver cancer through senescence secretome. Nature 2013, 499, 97-101. [CrossRef]

157. Krtolica, A.; Parrinello, S.; Lockett, S.; Desprez, P.Y.; Campisi, J. Senescent fibroblasts promote epithelial cell growth and tumorigenesis: A link between cancer and aging. Proc. Natl. Acad. Sci. USA 2001, 98, 12072-12077. [CrossRef]

158. Acosta, J.C.; O’Loghlen, A.; Banito, A.; Guijarro, M.V.; Augert, A.; Raguz, S.; Fumagalli, M.; Da Costa, M.; Brown, C.; Popov, N. Chemokine signaling via the CXCR2 receptor reinforces senescence. Cell 2008, 133, 1006-1018. [CrossRef]

159. Kuilman, T.; Michaloglou, C.; Vredeveld, L.C.; Douma, S.; van Doorn, R.; Desmet, C.J.; Aarden, L.A.; Mooi, W.J.; Peeper, D.S. Oncogene-induced senescence relayed by an interleukin-dependent inflammatory network. Cell 2008, 133, 1019-1031. [CrossRef]

160. Wajapeyee, N.; Serra, R.W.; Zhu, X.; Mahalingam, M.; Green, M.R. Oncogenic BRAF induces senescence and apoptosis through pathways mediated by the secreted protein IGFBP7. Cell 2008, 132, 363-374. [CrossRef] 
161. Kuilman, T.; Michaloglou, C.; Mooi, W.J.; Peeper, D.S. The essence of senescence. Genes Dev. 2010, 24, 2463-2479. [CrossRef] [PubMed]

162. Hanahan, D.; Weinberg, R.A. Hallmarks of cancer: The next generation. Cell 2011, 144, 646-674. [CrossRef] [PubMed]

163. Collado, M.; Gil, J.; Efeyan, A.; Guerra, C.; Schuhmacher, A.J.; Barradas, M.; Benguria, A.; Zaballos, A.; Flores, J.M.; Barbacid, M.; et al. Tumour biology: Senescence in premalignant tumours. Nature 2005, 436, 642. [CrossRef] [PubMed]

164. Collado, M.; Serrano, M. Senescence in tumours: Evidence from mice and humans. Nat. Rev. Cancer 2010, 10, 51-57. [CrossRef]

165. Bennett, D.C. Human melanocyte senescence and melanoma susceptibility genes. Oncogene 2003, 22, 3063-3069. [CrossRef]

166. Turner, N.C.; Ro, J.; Andre, F.; Loi, S.; Verma, S.; Iwata, H.; Harbeck, N.; Loibl, S.; Huang Bartlett, C.; Zhang, K.; et al. Palbociclib in Hormone-Receptor-Positive Advanced Breast Cancer. N. Engl. J. Med. 2015, 373, $209-219$. [CrossRef]

167. Goldman, J.W.; Shi, P.; Reck, M.; Paz-Ares, L.; Koustenis, A.; Hurt, K.C. Treatment Rationale and Study Design for the JUNIPER Study: A Randomized Phase III Study of Abemaciclib With Best Supportive Care Versus Erlotinib With Best Supportive Care in Patients With Stage IV Non-Small-Cell Lung Cancer With a Detectable KRAS Mutation Whose Disease Has Progressed After Platinum-Based Chemotherapy. Clin. Lung Cancer 2016, 17, 80-84.

168. Sherr, C.J.; Beach, D.; Shapiro, G.I. Targeting CDK4 and CDK6: From Discovery to Therapy. Cancer Discov. 2016, 6, 353-367. [CrossRef]

169. Geoerger, B.; Bourdeaut, F.; DuBois, S.G.; Fischer, M.; Geller, J.I.; Gottardo, N.G.; Marabelle, A.; Pearson, A.D.J.; Modak, S.; Cash, T.; et al. A Phase I Study of the CDK4/6 Inhibitor Ribociclib (LEE011) in Pediatric Patients with Malignant Rhabdoid Tumors, Neuroblastoma, and Other Solid Tumors. Clin. Cancer Res. 2017, 23, 2433-2441. [CrossRef]

170. Aceto, N.; Sausgruber, N.; Brinkhaus, H.; Gaidatzis, D.; Martiny-Baron, G.; Mazzarol, G.; Confalonieri, S.; Quarto, M.; Hu, G.; Balwierz, P.J.; et al. Tyrosine phosphatase SHP2 promotes breast cancer progression and maintains tumor-initiating cells via activation of key transcription factors and a positive feedback signaling loop. Nat. Med. 2012, 18, 529-537. [CrossRef]

171. Lan, L.; Holland, J.D.; Qi, J.; Grosskopf, S.; Rademann, J.; Vogel, R.; Gyorffy, B.; Wulf-Goldenberg, A.; Birchmeier, W. Shp2 signaling suppresses senescence in PyMT-induced mammary gland cancer in mice. Embo J. 2015, 34, 1493-1508. [CrossRef] [PubMed]

172. Llovet, J.M.; Ricci, S.; Mazzaferro, V.; Hilgard, P.; Gane, E.; Blanc, J.F.; de Oliveira, A.C.; Santoro, A.; Raoul, J.L.; Forner, A.; et al. Sorafenib in advanced hepatocellular carcinoma. N. Engl. J. Med. 2008, 359, 378-390. [CrossRef] [PubMed]

173. Gu, F.M.; Li, Q.L.; Gao, Q.; Jiang, J.H.; Huang, X.Y.; Pan, J.F.; Fan, J.; Zhou, J. Sorafenib inhibits growth and metastasis of hepatocellular carcinoma by blocking STAT3. World J. Gastroenterol 2011, 17, 3922-3932. [CrossRef] [PubMed]

174. Gedaly, R.; Angulo, P.; Hundley, J.; Daily, M.F.; Chen, C.; Evers, B.M. PKI-587 and sorafenib targeting $\mathrm{PI} 3 \mathrm{~K} / \mathrm{AKT} / \mathrm{mTOR}$ and Ras/Raf/MAPK pathways synergistically inhibit HCC cell proliferation. J. Surg. Res. 2012, 176, 542-548. [CrossRef] [PubMed]

175. Kudo, M.; Finn, R.S.; Qin, S.; Han, K.H.; Ikeda, K.; Piscaglia, F.; Baron, A.; Park, J.W.; Han, G.; Jassem, J.; et al. Lenvatinib versus sorafenib in first-line treatment of patients with unresectable hepatocellular carcinoma: A randomised phase 3 non-inferiority trial. Lancet 2018, 391, 1163-1173. [CrossRef]

176. Blivet-Van Eggelpoel, M.J.; Chettouh, H.; Fartoux, L.; Aoudjehane, L.; Barbu, V.; Rey, C.; Priam, S.; Housset, C.; Rosmorduc, O.; Desbois-Mouthon, C. Epidermal growth factor receptor and HER-3 restrict cell response to sorafenib in hepatocellular carcinoma cells. J. Hepatol. 2012, 57, 108-115. [CrossRef]

177. Zhai, B.; Sun, X.Y. Mechanisms of resistance to sorafenib and the corresponding strategies in hepatocellular carcinoma. World J. Hepatol. 2013, 5, 345-352. [CrossRef]

178. Childs, B.G.; Gluscevic, M.; Baker, D.J.; Laberge, R.-M.; Marquess, D.; Dananberg, J.; van Deursen, J.M. Senescent cells: An emerging target for diseases of ageing. Nat. Rev. Drug Discov. 2017, 16, 718. [CrossRef]

179. Ovadya, Y.; Krizhanovsky, V. Strategies targeting cellular senescence. J. Clin. Investig. 2018, 128, 1247-1254. [CrossRef] 
180. Soto-Gamez, A.; Demaria, M. Therapeutic interventions for aging: The case of cellular senescence. Drug Discov. Today 2017, 22, 786-795. [CrossRef]

181. Li, F.; Huangyang, P.; Burrows, M.; Guo, K.; Riscal, R.; Godfrey, J.; Lee, K.E.; Lin, N.; Lee, P.; Blair, I.A. FBP1 loss disrupts liver metabolism and promotes tumorigenesis through a hepatic stellate cell senescence secretome. Nat. Cell Biol. 2020, 22, 728-739. [CrossRef] [PubMed]

182. Wakita, M.; Takahashi, A.; Sano, O.; Loo, T.M.; Imai, Y.; Narukawa, M.; Iwata, H.; Matsudaira, T.; Kawamoto, S.; Ohtani, N. A BET family protein degrader provokes senolysis by targeting NHEJ and autophagy in senescent cells. Nat. Commun. 2020, 11,1-13. [CrossRef] [PubMed]

183. Fuhrmann-Stroissnigg, H.; Ling, Y.Y.; Zhao, J.; McGowan, S.J.; Zhu, Y.; Brooks, R.W.; Grassi, D.; Gregg, S.Q.; Stripay, J.L.; Dorronsoro, A. Identification of HSP90 inhibitors as a novel class of senolytics. Nat. Commun. 2017, 8, 1-14. [CrossRef] [PubMed]

184. Wang, R.; Yu, Z.; Sunchu, B.; Shoaf, J.; Dang, I.; Zhao, S.; Caples, K.; Bradley, L.; Beaver, L.M.; Ho, E. Rapamycin inhibits the secretory phenotype of senescent cells by a Nrf2-independent mechanism. Aging Cell 2017, 16, 564-574. [CrossRef]

185. Demaria, M.; Ohtani, N.; Youssef, S.A.; Rodier, F.; Toussaint, W.; Mitchell, J.R.; Laberge, R.-M.; Vijg, J.; Van Steeg, H.; Dollé, M.E. An essential role for senescent cells in optimal wound healing through secretion of PDGF-AA. Dev. Cell 2014, 31, 722-733. [CrossRef]

186. Herranz, N.; Gallage, S.; Mellone, M.; Wuestefeld, T.; Klotz, S.; Hanley, C.J.; Raguz, S.; Acosta, J.C.; Innes, A.J.; Banito, A.; et al. Erratum: mTOR regulates MAPKAPK2 translation to control the senescence-associated secretory phenotype. Nat. Cell Biol. 2015, 17, 1370. [CrossRef]

187. Laberge, R.M.; Sun, Y.; Orjalo, A.V.; Patil, C.K.; Freund, A.; Zhou, L.; Curran, S.C.; Davalos, A.R.; Wilson-Edell, K.A.; Liu, S.; et al. MTOR regulates the pro-tumorigenic senescence-associated secretory phenotype by promoting IL1A translation. Nat. Cell Biol. 2015, 17, 1049-1061. [CrossRef]

188. Wang, C.; Vegna, S.; Jin, H.; Benedict, B.; Lieftink, C.; Ramirez, C.; de Oliveira, R.L.; Morris, B.; Gadiot, J.; Wang, W.; et al. Inducing and exploiting vulnerabilities for the treatment of liver cancer. Nature 2019, 574, 268-272. [CrossRef]

189. Kucheryavenko, O.; Nelson, G.; von Zglinicki, T.; Korolchuk, V.I.; Carroll, B. The mTORC1-autophagy pathway is a target for senescent cell elimination. Biogerontology 2019, 20, 331-335. [CrossRef]

190. Al-Fayoumi, S.; Hashiguchi, T.; Shirakata, Y.; Mascarenhas, J.; Singer, J.W. Pilot study of the antifibrotic effects of the multikinase inhibitor pacritinib in a mouse model of liver fibrosis. J. Exp. Pharm. 2018, 10, 9-17. [CrossRef]

191. Wilson, G.S.; Tian, A.; Hebbard, L.; Duan, W.; George, J.; Li, X.; Qiao, L. Tumoricidal effects of the JAK inhibitor Ruxolitinib (INC424) on hepatocellular carcinoma in vitro. Cancer Lett. 2013, 341, 224-230. [CrossRef] [PubMed]

192. Zhu, Y.; Tchkonia, T.; Pirtskhalava, T.; Gower, A.C.; Ding, H.; Giorgadze, N.; Palmer, A.K.; Ikeno, Y.; Hubbard, G.B.; Lenburg, M. The Achilles' heel of senescent cells: From transcriptome to senolytic drugs. Aging Cell 2015, 14, 644-658. [CrossRef] [PubMed]

193. Ogrodnik, M.; Miwa, S.; Tchkonia, T.; Tiniakos, D.; Wilson, C.L.; Lahat, A.; Day, C.P.; Burt, A.; Palmer, A.; Anstee, Q.M.; et al. Cellular senescence drives age-dependent hepatic steatosis. Nat. Commun. 2017, 8, 15691. [CrossRef] [PubMed]

194. Moncsek, A.; Al-Suraih, M.S.; Trussoni, C.E.; O’Hara, S.P.; Splinter, P.L.; Zuber, C.; Patsenker, E.; Valli, P.V.; Fingas, C.D.; Weber, A.; et al. Targeting senescent cholangiocytes and activated fibroblasts with B-cell lymphoma-extra large inhibitors ameliorates fibrosis in multidrug resistance 2 gene knockout (Mdr2(-/-)) mice. Hepatology 2018, 67, 247-259. [CrossRef]

195. Hikita, H.; Takehara, T.; Shimizu, S.; Kodama, T.; Shigekawa, M.; Iwase, K.; Hosui, A.; Miyagi, T.; Tatsumi, T.; Ishida, H.; et al. The Bcl-xL inhibitor, ABT-737, efficiently induces apoptosis and suppresses growth of hepatoma cells in combination with sorafenib. Hepatology 2010, 52, 1310-1321. [CrossRef]

196. Guerrero, A.; Herranz, N.; Sun, B.; Wagner, V.; Gallage, S.; Guiho, R.; Wolter, K.; Pombo, J.; Irvine, E.E.; Innes, A.J.; et al. Cardiac glycosides are broad-spectrum senolytics. Nat. Metab. 2019, 1, 1074-1088. [CrossRef]

197. Lee, J.; Liao, R.; Wang, G.; Yang, B.H.; Luo, X.; Varki, N.M.; Qiu, S.J.; Ren, B.; Fu, W.; Feng, G.S. Preventive Inhibition of Liver Tumorigenesis by Systemic Activation of Innate Immune Functions. Cell Rep. 2017, 21, 1870-1882. [CrossRef] 
198. Amor, C.; Feucht, J.; Leibold, J.; Ho, Y.J.; Zhu, C.; Alonso-Curbelo, D.; Mansilla-Soto, J.; Boyer, J.A.; Li, X.; Giavridis, T.; et al. Senolytic CAR T cells reverse senescence-associated pathologies. Nature 2020, 583, 127-132. [CrossRef]

199. Singh, R.; Letai, A.; Sarosiek, K. Regulation of apoptosis in health and disease: The balancing act of BCL-2 family proteins. Nat. Rev. Mol. Cell Biol. 2019, 20, 175-193. [CrossRef]

200. Osman, H.; Gabr, O.; Lotfy, S.; Gabr, S. Serum levels of bcl-2 and cellular oxidative stress in patients with viral hepatitis. Indian J. Med. Microbiol. 2007, 25, 323.

201. Yang, Y.; Zhu, J.; Gou, H.; Cao, D.; Jiang, M.; Hou, M. Clinical significance of Cox-2, Survivin and Bcl-2 expression in hepatocellular carcinoma (HCC). Med. Oncol. 2011, 28, 796-803. [CrossRef] [PubMed]

202. Chang, J.; Wang, Y.; Shao, L.; Laberge, R.-M.; Demaria, M.; Campisi, J.; Janakiraman, K.; Sharpless, N.E.; Ding, S.; Feng, W. Clearance of senescent cells by ABT263 rejuvenates aged hematopoietic stem cells in mice. Nat. Med. 2016, 22, 78. [CrossRef] [PubMed]

203. Demaria, M.; O’Leary, M.N.; Chang, J.; Shao, L.; Liu, S.; Alimirah, F.; Koenig, K.; Le, C.; Mitin, N.; Deal, A.M. Cellular senescence promotes adverse effects of chemotherapy and cancer relapse. Cancer Discov. 2017, 7, 165-176. [CrossRef] [PubMed]

204. Schratt, G.; Philippar, U.; Hockemeyer, D.; Schwarz, H.; Alberti, S.; Nordheim, A. SRF regulates Bcl-2 expression and promotes cell survival during murine embryonic development. Embo J. 2004, 23, 1834-1844. [CrossRef] [PubMed]

205. Shaposhnikov, D.; Descot, A.; Schilling, J.; Posern, G. Myocardin-related transcription factor A regulates expression of Bok and Noxa and is involved in apoptotic signalling. Cell Cycle 2012, 11, 141-150. [CrossRef]

206. Leal, A.S.; Misek, S.A.; Lisabeth, E.M.; Neubig, R.R.; Liby, K.T. The Rho/MRTF pathway inhibitor CCG-222740 reduces stellate cell activation and modulates immune cell populations in Kras(G12D); Pdx1-Cre (KC) mice. Sci. Rep. 2019, 9, 7072. [CrossRef]

207. Llovet, J.M.; Zucman-Rossi, J.; Pikarsky, E.; Sangro, B.; Schwartz, M.; Sherman, M.; Gores, G. Hepatocellular carcinoma. Nat. Rev. Dis. Primers 2016, 2, 16018. [CrossRef]

208. Zucman-Rossi, J.; Villanueva, A.; Nault, J.C.; Llovet, J.M. Genetic Landscape and Biomarkers of Hepatocellular Carcinoma. Gastroenterology 2015, 149, 1226-1239. [CrossRef]

209. Sieben, C.J.; Sturmlechner, I.; van de Sluis, B.; van Deursen, J.M. Two-Step Senescence-Focused Cancer Therapies. Trends Cell Biol. 2018, 28, 723-737. [CrossRef]

210. Thapa, R.K.; Nguyen, H.T.; Jeong, J.H.; Kim, J.R.; Choi, H.G.; Yong, C.S.; Kim, J.O. Progressive slowdown/ prevention of cellular senescence by CD9-targeted delivery of rapamycin using lactose-wrapped calcium carbonate nanoparticles. Sci. Rep. 2017, 7, 43299. [CrossRef]

211. Muñoz-Espín, D.; Rovira, M.; Galiana, I.; Giménez, C.; Lozano-Torres, B.; Paez-Ribes, M.; Llanos, S.; Chaib, S.; Muñoz-Martín, M.; Ucero, A.C.; et al. A versatile drug delivery system targeting senescent cells. Embo Mol. Med. 2018, 10, e9355. [CrossRef] [PubMed]

Publisher's Note: MDPI stays neutral with regard to jurisdictional claims in published maps and institutional affiliations.

(C) 2020 by the authors. Licensee MDPI, Basel, Switzerland. This article is an open access article distributed under the terms and conditions of the Creative Commons Attribution (CC BY) license (http://creativecommons.org/licenses/by/4.0/). 